\title{
Synoptic patterns of meiofaunal and macrofaunal abundances and specific composition in littoral sediments
}

\author{
Werner Armonies \& Monika Hellwig-Armonies \\ Biologische Anstalt Helgoland (Litoralstation); D-2282 List/Sylt, \\ Federal Republic of Germany
}

\begin{abstract}
During recent years, many investigations on small zoobenthos have been performed at the island of Sylt. As these studies were carried out sporadically over many years and as different extraction methods were used, comparisons of the results have been hampered. Therefore, in August/September 1986, 24 sites were sampled and evaluated using one quantitative method throughout. Sites range from mud to exposed sand and from the sublittoral to the supralittoral. Macrofauna and the taxa Plathelminthes, Polychaeta, and Oligochaeta are determined to species level. Macrofaunal (>0.5 mm) abundance is highest in mud and continuously decreases with increasing exposure to wave action. Meiofaunal $(<0.5 \mathrm{~mm})$ abundance is less variable. Nematoda dominate in mud and muddy sand, Copepoda in sheltered and exposed sand, other taxa only intermittently. Related to surface area, no correlation between macro- and meiofaunal abundance is apparent. Plathelminthes and Copepoda reach highest abundance per surface area in sand but their per volume density is higher in mud and muddy sand. Related to sediment volume instead of surface area, the meiofaunal abundance pattern is very similar to the macrofaunal pattern. The faunal composition changes gradually along the tidal gradient without general faunal boundaries. On an averange, the faunal similarity of neighbouring sites is highest in Oligochaeta and lowest in Plathelminthes. Presumably, Oligochaeta tolerate wider ranges of environmental factors. This may explain the low number of oligochaete species. On the other hand, Plathelminthes seem to adapt to relatively narrow ranges of factors and their species richness is highest. Because of macrofaunameiofauna interaction it is suggested that the meiofaunal assemblage will be least stable in mud and muddy sand, and most stable in exposed sand.
\end{abstract}

\section{INTRODUCTION}

In the last 20 years, several investigations have been made on the small zoobenthos near the island of Sylt (North Sea). Due to the variety of habitats ranging from mud to coarse sand, from sublittoral to supralittoral, it has not been possible, up to now, to investigate all habitats simultaneously with one method throughout. The difficulties in meiofaunal species identification made the selection of a single meiofaunal taxon essential in most cases. The study of Schmidt (1968) is to some extent an exception. He studied the entire meiofauna of several beach transects. Depending on the studied taxon and the type of sediments, different methods of extraction were used. The seawater-ice method (Uhlig et al., 1973) proved useful for the extraction of Ciliata and some other taxa from relatively pure sand (Schmidt, 1968; Martens, 1984). The meiofauna of sheltered 
beaches may be extracted by a shaking-decantation procedure (Hellwig, 1987). In the case of exposed beaches additional magnesium chloride anaesthetization was proposed (Noldt \& Wehrenberg, 1984). Finally, the method proposed by Armonies \& Hellwig (1986) is suitable on muddy sediments only. In summary, none of these methods is equally efficient over all taxa and all types of sediment. We therefore used the tedious method of looking directly through all the sand grains.

The earlier studies were spread over many years. This is another reason, apart from the different methods of extraction, why the ecological results, such as species richness, abundance, and even the faunal composition of the various investigations were not comparable. This study is an attempt to reinvestigate simultaneously the fauna of some prominent sites, using just one (quantitative) method of extraction. Again, the huge number of meiofaunal species prohibited an evaluation to species level in all the taxa. Although all metazoan meiofauna was counted, only 3 taxa were determined to species level: (1) Plathelminthes, which live all over the tidal zone of the island of Sylt. (2) Oligochaeta, which invaded the sea from the land in the course of evolution. (3) Polychaeta (including "Archiannelida") are marine species, a few of which also penetrate brackish waters.

While almost all Plathelminth species are in the range of meiofauna, both Polychaeta and Oligochaeta cover a wider range of body sizes. Some of them may be termed meiofauna, others macrofauna. To avoid missing one of these components, two types of samples were collected: (1) "meiofaunal" samples, covering $1 \mathrm{~cm}^{2}$ of surface area. This sediment was sorted for meiofaunal organisms. (2) "macrofaunal" samples of $10 \mathrm{~cm}^{2}$ surface area each. These samples yield macrofaunal organisms which are too large, or too scanty to be recorded from a smaller area. Samples were sieved through $500 \mu \mathrm{m}$ meshes, and the residues are called macrofauna. However, at least in the case of Oligochaeta, the division into macro--and meiofauna did not prove to be useful.

\section{MATERIAL AND METHODS}

\section{Sample sites}

Twenty-four sites were sampled during August and September 1986 on the island of Sylt (North Sea). The climate is subatlantic. The average water temperature is $4.5^{\circ} \mathrm{C}$ in winter and $15.1{ }^{\circ} \mathrm{C}$ in summer. Salinity varies between 27 and $31 \%$. Tidal range ist about $1.8 \mathrm{~m}$.

The sites are arranged in 4 profiles (cf. Fig. 1). (1) The western beach which is exposed to the open sea without any shelter (termed "exposed sand"). (2) A coarse grained, sheltered (semi-exposed) beach at the eastern side of the island (termed "sheltered sand"). (3) Sheltered muddy sand of the Königshafen Wadden area ("muddy sand"). (4) Mud from the Königshafen and a Spartina marsh north of the village of Kampen (termed "mud").

General remarks on the hydrographic conditions of the island of Sylt, and a detailed description of profile (2) are given by Schmidt (1968). He also describes a site very similar to profile 1 (his station 1). This locality was intermittently disturbed by a gale. The sampled "mud" sites are sandy mud rather than pure mud. The sediment composition shows strong small-scale differences in most of the 24 sites. Much of the small-scale 
faunal differences leading to significant deviations of abundance from randomness is due to these differences in sediment composition. Therefore, giving values of single analyses of sediment composition is, it seems, not very useful. Similarly, it was impossible to find 6 sites (of a profile) that are identical in sediment composition. Therefore, when the sites were selected, a similar range of small-scale differences in the sediment composition of all 6 sites was the prominent criterion.

Each of the 4 profiles has 6 distinct sampling stations, which are termed according to the annual mean percentage of tidal emergence time:

(1) No. " 0 " are sublittoral samples, 2-3 m below mean low tide level (MLTL) in mud and muddy sand, and 15 to $20 \mathrm{~m}$ below MLTL in sheltered and exposed sand.

(2) No. "1" terms sample sites about $20 \mathrm{~cm}$ below MLTL (annual mean of tidal emergence time about $1 \%$ ).

(3) No. "10", about $20 \mathrm{~cm}$ above MLTL, tidal emergence about $10 \%$.

(4) No. " $50 "$ ", mid tide level, $50 \%$ emergence.

(5) No. "90", about $20 \mathrm{~cm}$ below mean high tide level (MHTL), $90 \%$ emergence.

(6) No. "99", about $20 \mathrm{~cm}$ above MHTL, emergence time about $99 \%$.

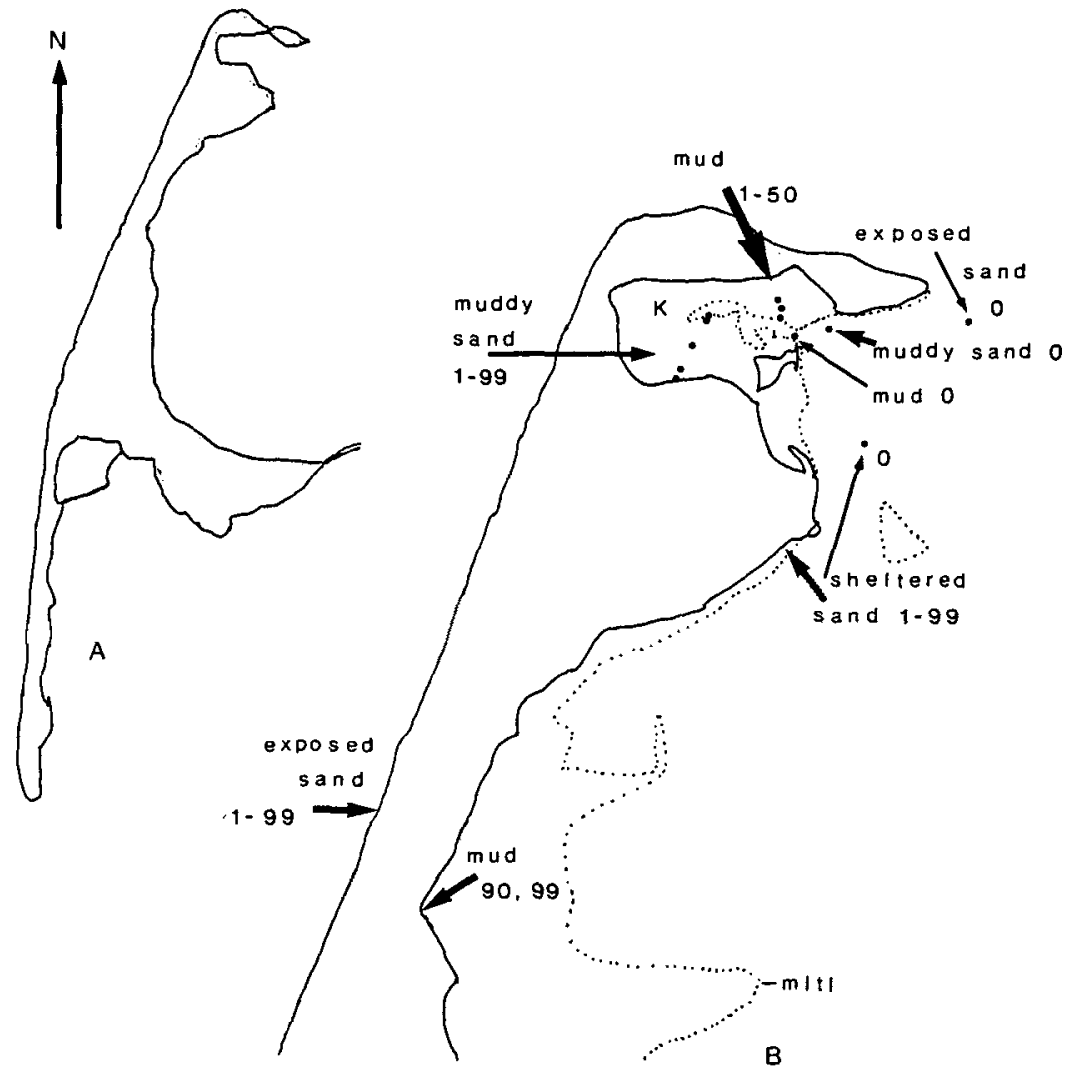

Fig. 1. (A) The island of Sylt. (B) Northern part of the island with sample sites. Numbers denote the height of sample sites in terms of the percentage of tidal emergence. mltl = mean low tide level 
This arrangement was chosen in order to test the hypothesis that MHTL and MLTL could be boundaries in species distribution. With 2 exceptions, all sites were devoid of spermatophyte vegetation. "Mud 99'" was covered with Spartina anglica Hubbard, and in "muddy sand 50" there was sparse growth of the sea grasses Zostera marina L. and $Z$. noltii Hornem.

\section{Sampling}

Two sets of samples were collected at every site: (1) "meiofaunal" samples covering $1 \mathrm{~cm}^{2}$ of surface area, and (2) "macrofaunal" samples of $10 \mathrm{~cm}^{2}$ surface area each. 10 replicates of both sample sizes were collected at every site using $10 \mathrm{~cm}^{2}$ plastic tubes 0.4 to $2 \mathrm{~m}$ in length. In the beaches, these tubes were repeatedly pushed into the same hole, yielding a 5 to $10 \mathrm{~cm}$ sediment column every time. Meiofaunal samples were subsampled from such cores (only 1 subsample per core) using a $1 \mathrm{~cm}^{2}$ glass tube.

There were 3 sampling occasions. (1) Between August 1st and 18th, 5 meiofaunal samples $\left(1 \mathrm{~cm}^{2}\right.$ surface area) were collected at each of the eu- and supralittoral sites. (2) Between August 18th and 30th, the sublittoral samples were collected with a modified Reineck box-corer (cf. Wehrenberg \& Reise, 1985). 1 meiofaunal and 1 macrofaunal sample were taken from every box-core. Only cores containing more than $10 \mathrm{~cm}$ of sediment height were used. (3) Between September 4th and 30th, another 5 meiofaunal and all 10 macrofaunal samples were collected at each of the eu- and supralittoral sites.

Vertically, the sublittoral samples reached down as far as possible (maximum depth $30 \mathrm{~cm}$ in a core of sheltered sand). In the intertidal areas, the aerobic layer plus the top $20 \mathrm{~cm}$ of the anoxic (black or grey) layer was sampled. On the beaches, sampling was restricted to about $20 \mathrm{~cm}$ below ground water level. Vertically, the sediment columns were divided as follows: macrofaunal samples: the uppermost $10 \mathrm{~cm}$ in $5 \mathrm{~cm}$ layers, deeper layers in $10 \mathrm{~cm}$ portions (equivalent to 50 and $100 \mathrm{~cm}^{3}$, respectively). Meiofauna samples from the sublittoral and beaches were subdivided as the macrofauna samples. Meiofauna samples from the intertidal and from all mud areas: the uppermost $5 \mathrm{~cm}$ in $1 \mathrm{~cm}$ intervals, the 5 to $10 \mathrm{~cm}$ layer as a whole, deeper layers in portions of $10 \mathrm{~cm}$ (equivalent to 1,5 , and $10 \mathrm{~cm}^{3}$ of sediment).

\section{Extraction}

None of the previously used methods of meiofaunal extraction yields quantitative extraction in all types of sediment and on all meiofaunal taxa (Martens, 1984; Noldt \& Wehrenberg, 1984; Armonies \& Hellwig, 1986). Therefore, all the sediment was divided into Petri dishes and meiofauna was sorted from these dishes. However, to save time, the meiofauna of sandy sediment was concentrated by a shaking-decantation procedure prior to sorting. Samples ( 1 to $10 \mathrm{~cm}^{3}$ of sediment, see above) were washed into a beaker $\left(600 \mathrm{~cm}^{3}\right)$. Filtered sea water was added (about $50 \mathrm{~cm}^{3}$ ) and the beaker was gently shaken. Then the supernatant was decanted into a second beaker. Intensifying shaking and rotating, this procedure was repeated about 10 times. The final 2 washes were carried out using fresh water instead of sea water. If the fresh water application was no 
longer than $1 \mathrm{~min}$, no harm was done to the organisms. Instead, many animals formerly attached to sand grains lost hold of their anchors. However, the fresh water treatment was omitted in the sublittoral samples. Species living here never experience such strong salinity changes and might get damaged.

The gathered supernatants were concentrated by sieving through $500 \mu \mathrm{m}$ (retains macrofauna) and $40 \mu \mathrm{m}$ meshes. The residues were transferred into Petri dishes with filtered sea water. The sediment left in the beaker was divided into 2 (coarse sand) to about 20 (muddy sand) Petri dishes as well. Mud was divided into Petri dishes (up to 50) without concentrating. From all these dishes the fauna was sorted and all major taxa counted.

In muddy sand and sheltered sand, the shaking-decantation procedure alone yielded quantitative extraction. Only occasionally did a specimen remain in the remaining sand. In retrospect, controlling all this sand gave no advantage over merely applying the shaking-decantation procedure (for an appropriate test see Hellwig, 1987). Extraction efficiency of the shaking-decantation procedure was higher than $90 \%$ even in exposed sand where most of the non-extracted individuals belong to the proseriate plathelminth species Nematoplana coelogynoporoides Meixner, 1938; these specimens were picked out of the "sediment dishes".

Macrofaunal samples were washed through $500 \mu \mathrm{m}$-meshes. Animals were sorted alive and determined to species level using a stereo microscope, or compound microscope if necessary.

\section{Counting and statistical analyses}

The macrofaunal samples were completely evaluated. In meiofaunal samples, counting of all taxa was too time consuming to be practised in all of the replicates. Therefore, only Plathelminthes, Polychaeta, and Oligochaeta were completely counted and determined to species level. The non-plathelminth meiofaunal taxa were only counted from the 5 replicates collected during the sampling occasion in September. The sublittoral samples are an exception: here, all (10) parallels were completely evaluated.

Generally, abundance of the major taxa shows significant deviation from randomness (significant deviation of the variance-to-mean ratio from the appropriate reference of a chi square table (cf. Gage \& Geekie, 1973). Strong aggregation is the rule. Therefore, the means given in tables and figures are only rough approximations. Accordingly, non parametrical tests are an adequate means of statistical evaluation. Here, the nonparametrical U-test (Wilcoxon et al., in Sachs 1984) is used.

Faunal affinities between sites are expressed with Renkonen's index $\left(R=\Sigma p_{i}\right.$, with $p_{i}$ being the portion of animals in the site where species $i$ is less abundant) and Sørensen's index $(S=2 j /[a+b]$, with $j$ being the joint number of species, and $a$ and $b$ the number of species in both sites). While $S$ expresses the fraction of species in common, $R$ evaluates the significance of every species. Thus, $R$ gives the affinity in terms of dominants rather than species.

Species diversity is characterized by Shannon's entropy $\left(H^{\prime}=-\Sigma p_{i} \cdot \ln p_{i}\right.$, where $p_{i}$ is the proportion of the $i-$ th species, $i=1,2,3, \ldots S$ ). 


\section{RESULTS}

\section{Total macrofaunal and meiofaunal abundance}

Macrofauna is significantly more abundant in mud and muddy sand than in sheltered and exposed sand (Fig. 2). On an average, 83 individuals per $10 \mathrm{~cm}^{2}$ live in mud, .32 in muddy sand, 7 in sheltered sand, and 1 per $10 \mathrm{~cm}^{2}$ in exposed sand. In mud, abundance increases significantly in a landward direction up to the supralittoral site. Within the other types of sediment, the landward increase is already stopped at MHTL or there is no significant increase at all.

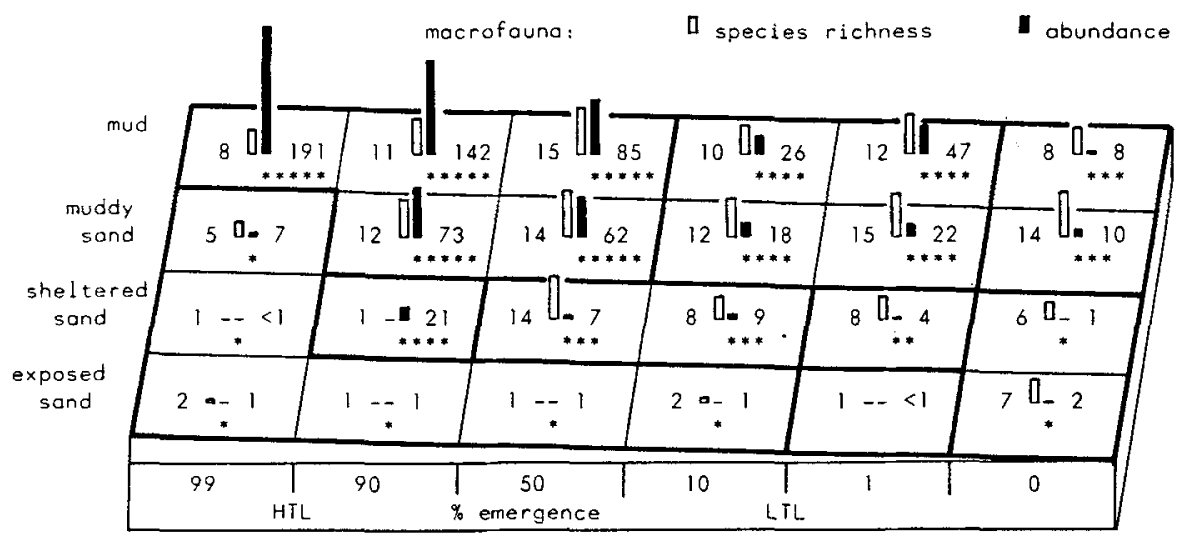

Fig. 2. Macrofaunal abundance (right numbers and dark columns) and species richness (left numbers and columns). Abundance: individuals per $10 \mathrm{~cm}^{2}$ of surface area; species richness: number of species per $100 \mathrm{~cm}^{2}$ of surface area. Abundance does not significantly differ between fields with the same number of asterisks ("), but is significantly higher in fields with a higher number of asterisks (U-test, $\mathrm{p} \leq 5 \%$ ). Bold lines enclose adjoining fields with the same number of asterisks. $0,1,10,50,50,90,99:$ percentage tidal emergence of the sample sites. HTL: mean high tide level, LTL mean low tide level

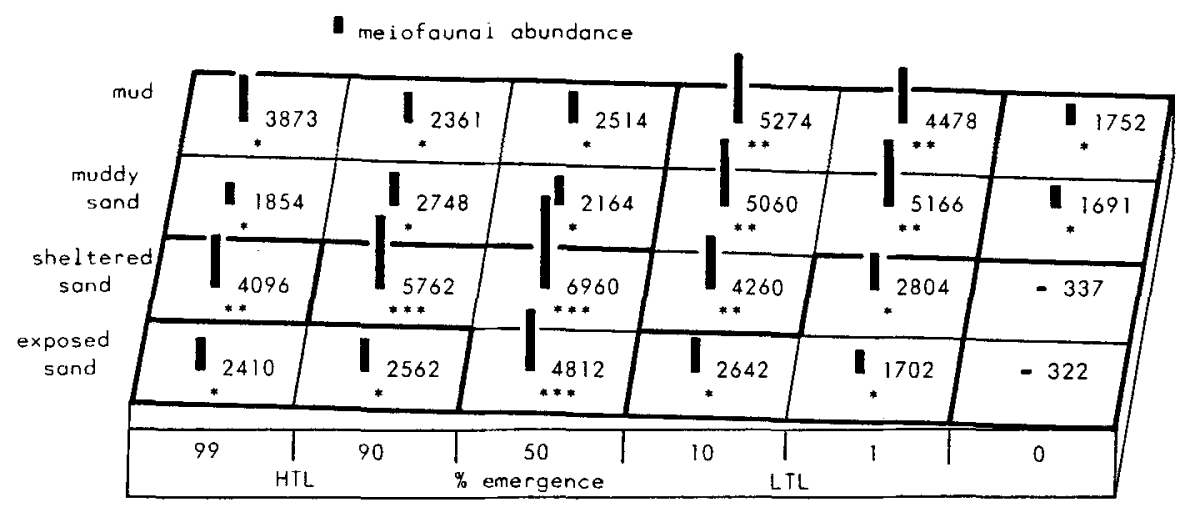

Fig. 3. Meiofaunal abundance (individuals per $10 \mathrm{~cm}^{2}$ surface area). For further explanations see Figure 2 
Meiofaunal abundance (Fig. 3) is less variable than macrofaunal abundance. Highest values are found in sheltered sand 50 and 90 . In exposed sand 50, the mean abundance is in the same range as in the lower intertidal mud and muddy sand. Nevertheless, U-test indicates a significant difference ( $\mathrm{p} \leq 5 \%$ ), which is due to the stronger patchiness of individuals in the lower intertidal mud and muddy sand sites. In each type of sediment, highest abundance is found in the intertidal: around MLTL in mud and muddy sand, at mid tide level and site 90 in sheltered sand, and at mid tide level in exposed sand.

There is no significantly negative correlation between meiofaunal and macrofaunal abundances. In mud and muddy sand, relatively high macrofaunal abundance occurs together with rather low meiofaunal abundance (upper intertidal), or both macrofauna and meiofauna reach intermediate abundance (lower intertidal; Figs 2 and 3). In sheltered sand, high meiofaunal abundance (indicated by ".*** in Fig. 3) meets high (site 90, $\cdots \cdots \cdots$ in Fig. 2) or intermediate (site 50, "**") macrofaunal abundance. In exposed sand, meiofauna is not exceptionally abundant, but since macrofauna is scarce meiofauna clearly dominates at these sites.

\section{Taxonomic composition}

A total of 61 macrofaunal species were found (Table 4). Polychaeta are richest in species (31), followed by Oligochaeta (11), Crustacea (9), and Mollusca (7 species). On an average of all sites, about 8 species were found per $100 \mathrm{~cm}^{2}$ of surface area. Species density is highest in mud and muddy sand and lowest in exposed sand (Fig. 2).

Polychaeta and Oligochaeta are both most abundant in mud and muddy sand, and least in exposed sand (Figs 4,5). Species number of macrofaunal Oligochaeta shows an identical tendency (Fig.5), while this tendency is less prominent in macrofaunal Polychaeta (Fig. 4). This is also seen when comparing the diversity ( $\mathrm{H}^{\prime}$ ) values (Table 1 ). In mud, abundance of macrofaunal Oligochaeta does not significantly differ between the supralittoral and the eulittoral sites, but is significantly lower at the sublittoral site. In muddy sand, abundance in both supralittoral and sublittoral is significantly lower than in the eulittoral (Fig.5). Abundance of macrofaunal Polychaeta was never significantly lower in the sublittoral sites than in the adjacent eulittoral, and it was never significantly higher in the supralittoral (Fig. 4).

The body size of Polychaeta and Oligochaeta varies widely. Some species are small enough to pass the meshes of a $500 \mu \mathrm{m}$ sieve and are therefore attributed to meiofauna. Specimens retained on a $500 \mu \mathrm{m}$ gauze are termed macrofauna. The patterns of smaller and larger annelids are not congruent (Figs 4-7). Larger annelids are most abundant in mud and muddy sand (Figs 4,5), smaller annelids in sheltered sand, exposed sand, and supralittoral mud (Figs 6,7 ). Although small specimens of both taxa are more abundant than the larger ones in most sites, they only locally play a major role in meiofaunal composition.

Nematoda dominate the meiofaunal assemblage of mud and muddy sand (up to $96 \%$ of small metazoons, Fig. 8). Abundance is highest in mud and muddy sand around MLTL. In exposed sand they only play a minor role: abundance is low from the sublittoral to mid tide level but increases significantly further landwards (Fig. 8).

Contrary to Nematoda, Copepoda are most abundant in eulittoral sheltered and 
Table 1. Diversity $\mathrm{H}^{\prime}$ and species richness (S) of total macrofauna, Polychaeta, and Oligochaeta. The H'-values for "all sediments" and "all heights" are computed on the totals, not averages. 0, 1, 10, 50, 90, 99: percentages of tidal emergence. -: not occupied by the respective taxon

\begin{tabular}{|c|c|c|c|c|c|c|c|c|}
\hline \multirow{2}{*}{ Taxa } & \multirow{2}{*}{$\begin{array}{c}\mathbf{0} \\
\mathrm{H}^{\prime}\end{array}$} & \multirow{2}{*}{$\begin{array}{c}1 \\
\mathrm{H}^{\prime}\end{array}$} & \multirow{2}{*}{$\begin{array}{l}10 \\
\mathrm{H}^{\prime}\end{array}$} & \multirow{2}{*}{$\begin{array}{l}50 \\
\mathrm{H}^{\prime}\end{array}$} & \multirow{2}{*}{$\begin{array}{l}90 \\
\mathrm{H}^{\prime}\end{array}$} & \multirow{2}{*}{$\begin{array}{l}99 \\
\mathrm{H}^{\prime}\end{array}$} & \multicolumn{2}{|c|}{ All heights } \\
\hline & & & & & & & $\mathbf{H}^{\prime}$ & $\mathbf{S}$ \\
\hline \multicolumn{9}{|l|}{ Mud } \\
\hline Macrofauna & 1.59 & .70 & 1.08 & 1.36 & 1.09 & .95 & 1.83 & 30 \\
\hline Polychaeta & 1.13 & 1.63 & 1.34 & 1,44 & 1.27 & 0 & 2.05 & 15 \\
\hline Oligochaeta & 0 & .30 & .66 & .69 & .65 & .42 & 1.30 & 8 \\
\hline \multicolumn{9}{|l|}{ Muddy sand } \\
\hline Macrofauna & 2.21 & 1.81 & 1.81 & 1.28 & 1.48 & .45 & 2.07 & 36 \\
\hline Polychaeta & 1.78 & 1.47 & 1.52 & .72 & .84 & - & 1.92 & 18 \\
\hline Oligochaeta & 0 & .36 & .41 & .66 & .71 & .56 & .72 & 5 \\
\hline \multicolumn{9}{|l|}{ Sheltered sand } \\
\hline Macrofauna & 1.61 & 1.53 & .98 & 1.83 & 0 & $\mathbf{0}$ & 2.21 & 22 \\
\hline Polychaeta & 1.04 & 1.53 & .89 & 1.61 & - & - & 1.87 & 15 \\
\hline Oligochaeta & - & - & 0 & - & - & - & 0 & 1 \\
\hline \multicolumn{9}{|l|}{ Exposed sand } \\
\hline Macrofauna & 1.57 & 0 & .67 & 0 & 0 & .69 & 1.58 & 9 \\
\hline Polychaeta & 1.43 & - & 0 & 0 & - & - & 1.32 & 7 \\
\hline Oligochaeta & 0 & - & - & - & - & - & 0 & 1 \\
\hline \multicolumn{9}{|l|}{ All sediments } \\
\hline Macrofauna & 2.66 & 1.56 & 2.01 & 2.01 & 1.49 & .97 & 2.15 & 61 \\
\hline Polychaeta , $\mathrm{H}^{\prime}$ & 2.13 & 2.07 & 1.99 & 2.16 & 1.31 & .65 & 2.51 & \\
\hline $\mathrm{S}$ & 16 & 17 & 16 & 17 & 9 & 2 & & 31 \\
\hline Oligochaeta $\mathrm{H}^{\prime}$ & .68 & .30 & .63 & .82 & .95 & .45 & 1.32 & \\
\hline $\mathbf{S}$ & 2 & 2 & 2 & 3 & 6 & 5 & & 11 \\
\hline
\end{tabular}

exposed sand. In mud and muddy sand, abundance tends to increase towards the land (Fig. 9).

Plathelminthes have an abundance pattern similar to Copepoda. The highest

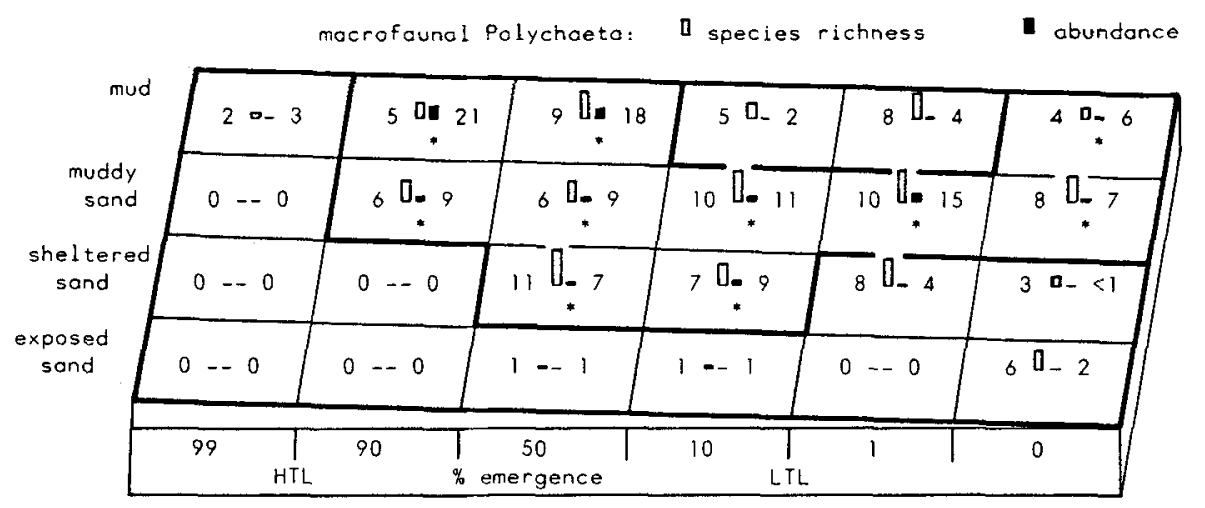

Fig. 4. Macrofaunal polychaete abundance (right numbers) and species richness (left). For further explanations see Figure 5 


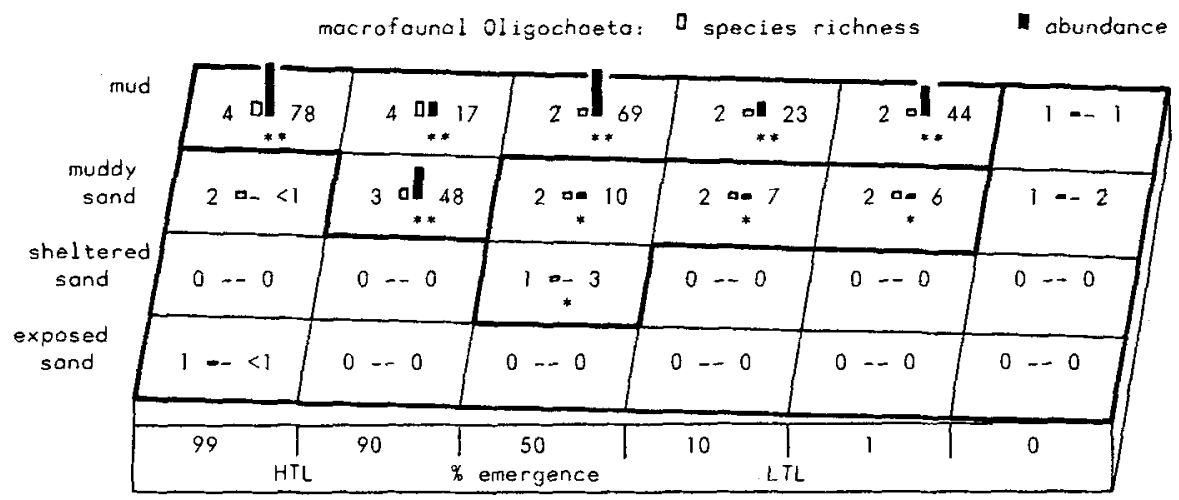

Fig. 5. Macrofaunal oligochaete abundance (right numbers, individuais per $10 \mathrm{~cm}^{2}$ of surface area) and species nichness (left numbers, species per $100 \mathrm{~cm}^{2}$ of surface area). Abundance does not significantly differ between fields with the same number of asterisks, but is significantly higher in fields with a higher number of asterisks (U-test, $p \leq 5 \%$ )

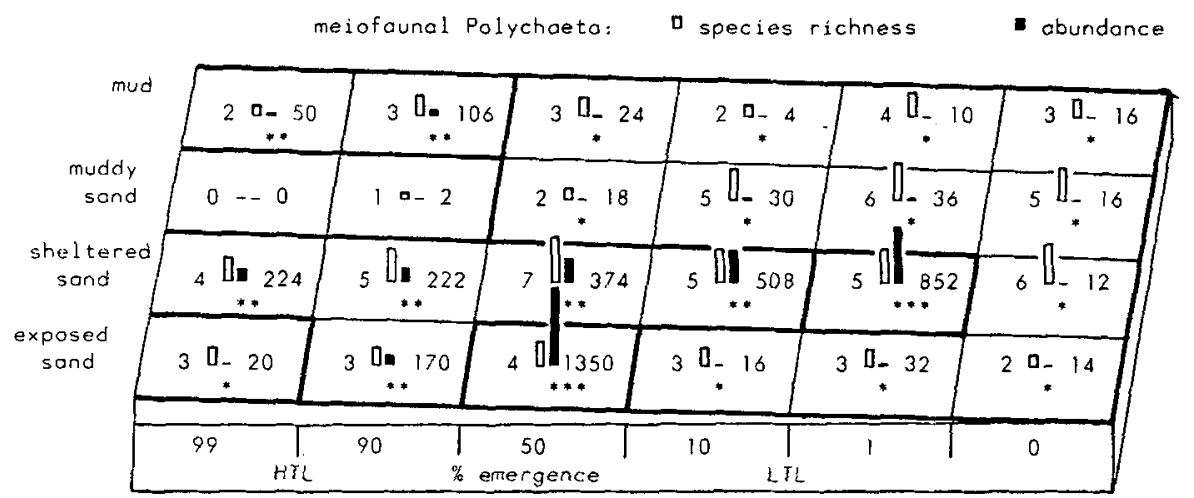

Fig. 6. Meiofaunal polychaete abundance (right numbers) and species richness (left). For further explanations see Figure 7

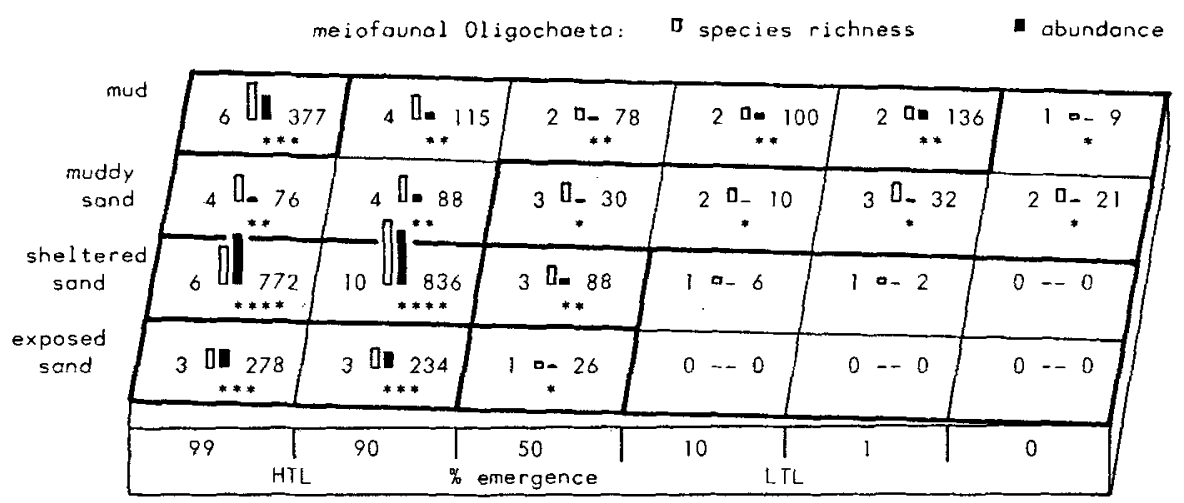

Fig. 7. Meiofaunal oligochaete abundance (right numbers, individuals per $10 \mathrm{~cm}^{2}$ of surface area) and species richness (left numbers, species per $10 \mathrm{~cm}^{2}$ of surface area). Abundance does not significantly differ between fields with the same number of asterisks, but is significantly higher in fields with a higher number of asterisks (U-test, $p \leq 5 \%$ ) 


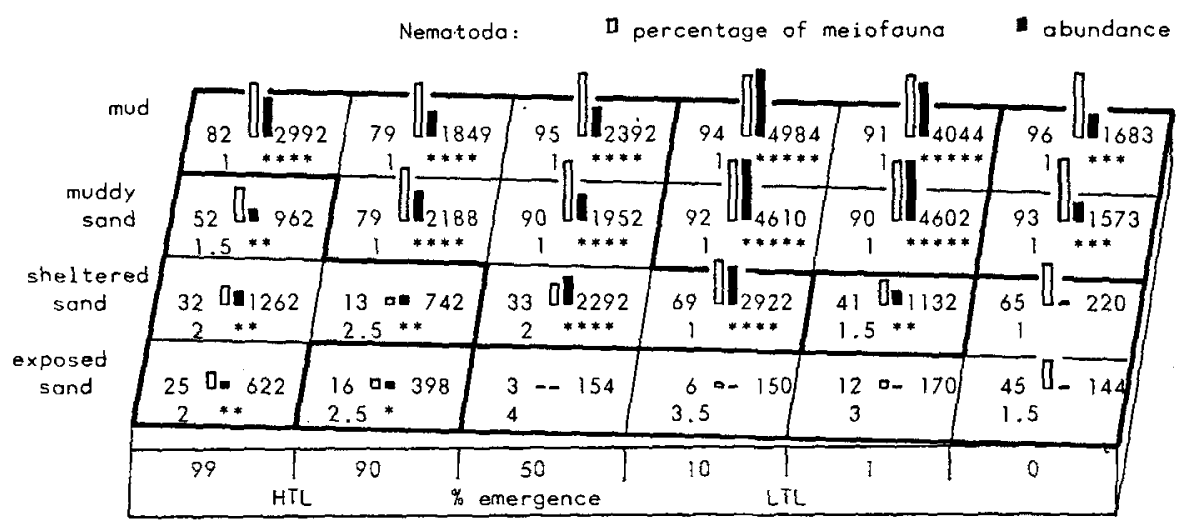

Fig. 8. Nematode abundance (right), percentage of total meiofauna (left), and the relative rank (below). For further explanations see Figure 9

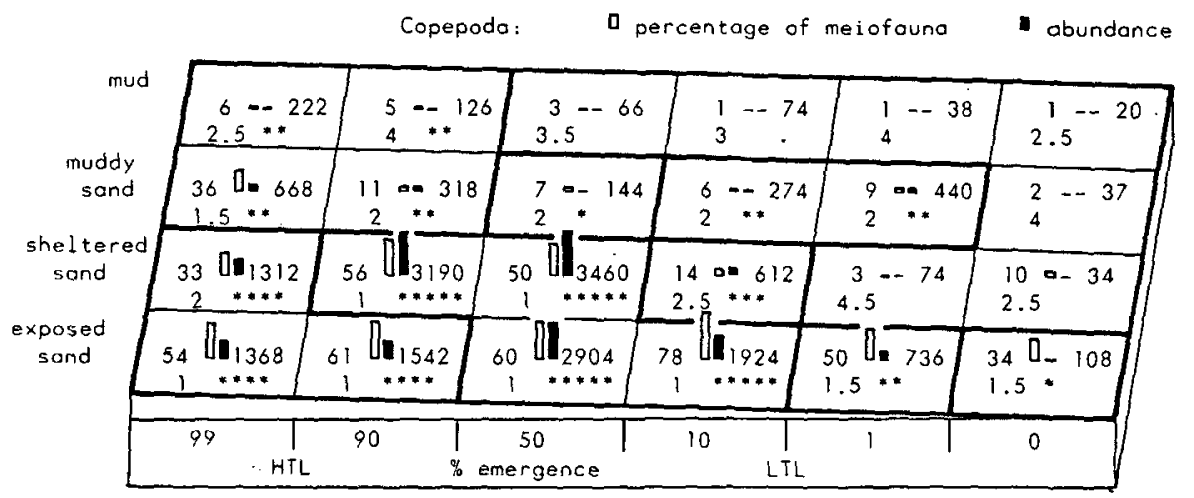

Fig. 9. Copepode abundance (right numbers), percentage of total meiofauna (left numbers), and the relative rank of meiofaunal abundances (lower left number). Abundance: individuals per $10 \mathrm{~cm}^{2}$ of surface area. Abundance does not significantly differ between fields with the same number of asterisks, but is significantly higher in fields with a higher number of asterisks (U-test, $\mathrm{p} \leq 5 \%$ ). Rank: 1 = significantly most abundant taxon, 2 = less abundant than 1 but significantly more abundant than 3 , and so on. Broken ranks indicate that there was no significant differences between 2 or more taxa, all got the intermediate rank (U-test, $p \leq 5 \%$ )

averages are found in the surf beaten zones of exposed sand $(1,10,50)$ and sheltered sand $(50,90$; cf. Fig. 10). There is no general landward trend in abundance. Although Ostracoda are present in most sites, they never attained local dominance (Fig. 11).

Most of the sites are dominated by Nematoda (mud, muddy sand) or Copepoda (sheltered and exposed sand). Locally, however, there were also other dominants (or codominants if there was no significant difference in the abundance of compared taxa). Plathelminthes (the species Nematoplana coelogynoporoides, above all) dominated in exposed sand 1 ( $>400 \cdot 10 \mathrm{~cm}^{-2}, 25 \%$ of all metazoans). Gastrotricha reached highest abundance in sheltered sand $1\left(432 \cdot 10 \mathrm{~cm}^{-2}\right.$, about $15 \%$ of all metazoans). The polychaete Protodrilus symbioticus was most abundant in sheltered sand 1,10 , and 50 $\left(832,484\right.$, and 232 individuals per $10 \mathrm{~cm}^{2}$ respectively, which is about $24 \%, 12 \%$, and 


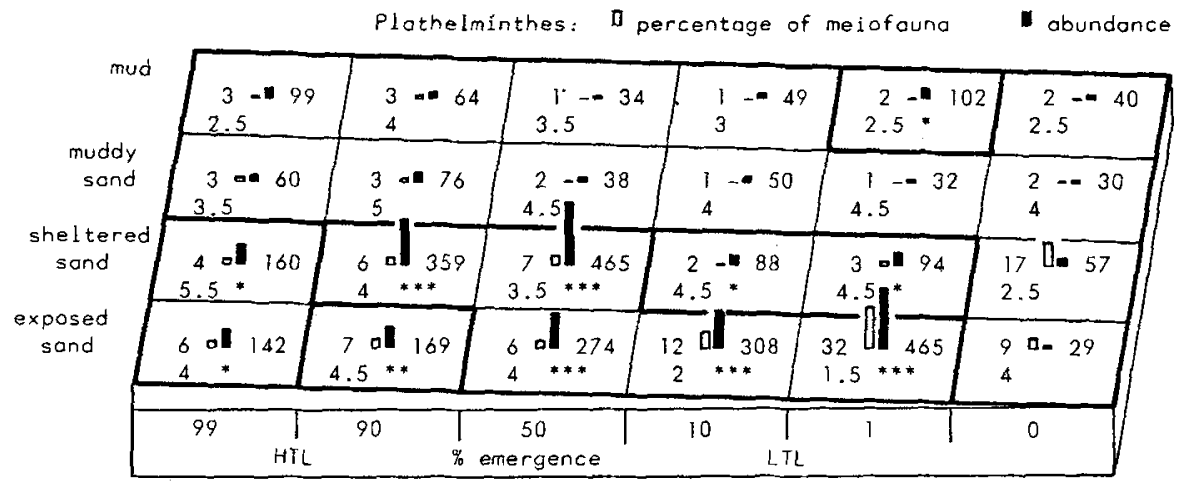

Fig. 10. Plathelminth abundance (right), percentage of total meiofauna (left), and the relative rank (below). For further explanations see Figure 9

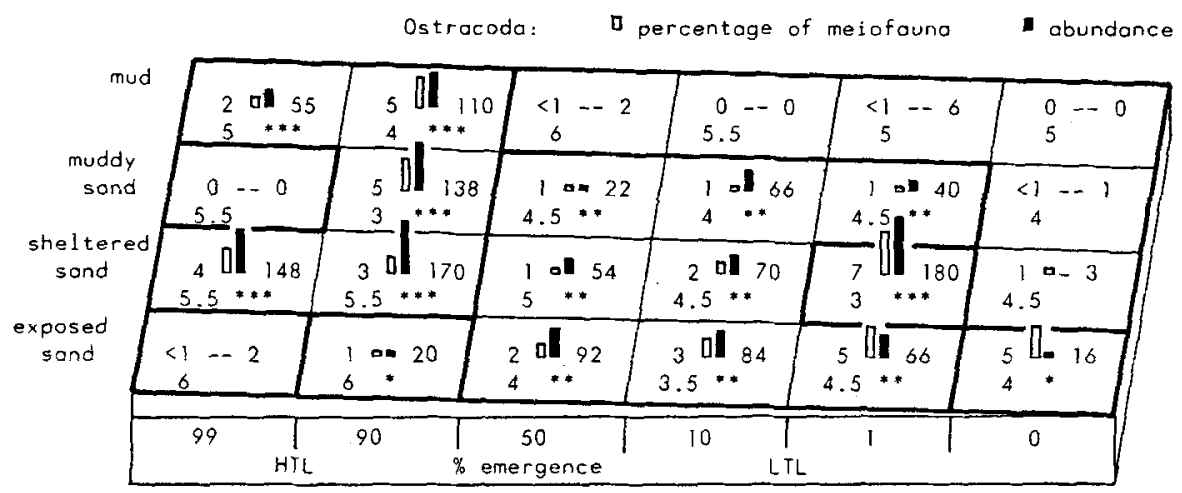

Fig. 11. Ostracode abundance (right), percentage of total meiofauna (left), and the relative rank (below). For further explanations see Figure 9

$3 \%$ of metazoans). Trilobodrilus axi attained highest abundance in exposed sand 50 $\left(1118 \cdot 10 \mathrm{~cm}^{-2}, 24 \%\right.$ of metazoans). Finally, Oligochaeta were most prominent in sheltered sand $99\left(772 \cdot 10 \mathrm{~cm}^{-2}\right.$, about $18 \%$ of metazoans $)$.

In Polychaeta and Oligochaeta, the larger (macrofaunal) species are significantly more abundant in mud and muddy sand than in sheltered and exposed sand (Figs 4,5). In small (meiofaunal) specimens of these taxa there is an opposite tendency: highest values are reached in sheltered and exposed sand (Figs 6, 7). Essentially, this marks the transition from a burrowing mode of life towards living in the interstitial pore system of coarse grained sediments. In sheltered sand, the interstitial species are found together with young of burrowing macrofaunal Polychaeta, causing the number of species to be highest. However, because of the influence of local dominants, the diversity $\mathrm{H}^{\prime}$ does not show the same tendency (Table 2). When compared to meiofaunal Oligochaeta, high abundance of few meiofaunal polychaete species is the cause for their lower diversity $\mathrm{H}^{\circ}$ (2.26 vs. 1.84), although Polychaeta are richer in species (21 vs. 29).

Since Polychaeta are a marine group, a landward decrease is expected. As concerns macrofaunal Polychaeta, this tendency is apparent. Only 2 species were found in the 
Table 2. Diversity $H^{\prime}$ and species richness (S) of meiofaunal Polychaeta and Oligochaeta. For further explanations see Table 1

\begin{tabular}{|c|c|c|c|c|c|c|c|c|}
\hline \multirow[t]{2}{*}{ Taxa } & \multirow{2}{*}{$\begin{array}{c}0 \\
\mathrm{H}^{\prime}\end{array}$} & \multirow{2}{*}{$\begin{array}{c}1 \\
\mathrm{H}^{\prime}\end{array}$} & \multirow{2}{*}{$\begin{array}{l}10 \\
\mathrm{H}^{\prime}\end{array}$} & \multirow{2}{*}{$\begin{array}{l}50 \\
\mathrm{H}^{\prime}\end{array}$} & \multirow{2}{*}{$\begin{array}{l}90 \\
\mathrm{H}^{\prime}\end{array}$} & \multirow{2}{*}{$\begin{array}{l}99 \\
\mathrm{H}^{\prime}\end{array}$} & \multicolumn{2}{|c|}{ All heights } \\
\hline & & & & & & & $\mathbf{H}^{\prime}$ & $\mathbf{S}$ \\
\hline \multicolumn{9}{|l|}{ Mud } \\
\hline Polychaeta & 1.08 & 1.33 & .69 & 1.01 & .71 & .16 & 1.38 & 11 \\
\hline Oligochaeta & 0 & .24 & .63 & .52 & 1.06 & 1.35 & 1.53 & 9 \\
\hline \multicolumn{9}{|l|}{ Muddy sand } \\
\hline Polychaeta & 1.49 & 1.52 & 1.08 & .69 & 0 & - & 1.96 & 10 \\
\hline Oligochaeta & .19 & .60 & .86 & .88 & .65 & 1.37 & 2.03 & 11 \\
\hline \multicolumn{9}{|l|}{ Sheltered sand } \\
\hline Polychaeta & 1.63 & .14 & .25 & 1.28 & 1.00 & .96 & 1.22 & 18 \\
\hline Oligochaeta & - & 0 & 0 & .25 & .66 & .19 & .55 & 14 \\
\hline \multicolumn{9}{|l|}{ Exposed sand } \\
\hline Polychaeta & .60 & 1.01 & .90 & .57 & .86 & .71 & .79 & 8 \\
\hline Oligochaeta & - & - & - & $\mathbf{0}$ & .35 & .20 & .34 & 3 \\
\hline \multicolumn{9}{|l|}{ All sediments } \\
\hline Polychaeta & 2.30 & .49 & .68 & 1.30 & 1.69 & 1.39 & 1.84 & 29 \\
\hline Oligochaeta & .64 & .27 & .75 & 1.40 & 2.07 & 1.69 & 2.26 & 21 \\
\hline
\end{tabular}

supralittoral zone (Fig. 4, Table 1). The small species, however, show no significant decrease in mud and exposed sand, and in sheltered sand the landward decrease is less pronounced than in macrofaunal Polychaeta (Fig. 6, Table 2).

In contrast, Oligochaeta are a limnic/terrestric taxon with some species invading the sea. Therefore, a seaward decrease is expected. The species numbers really decrease seawards (Figs 5,7); however, the highest number of species was found in sheltered sand 90 , and not in the most landward supralittoral sites. The abundance decreases seawards as well, but there are significant differences between the sediment types (Fig. 7).

Plathelminthes are present in marine as well as limnic areas. Nevertheless, in mud there is a clear landward increase in species numbers and diversity (Table 3), but there is no clear tendency in the other types of sediment (Fig. 12). All heights united, the number of species increases from mud to sheltered sand but drops in exposed sand. Compared to meiofaunal Polychaeta and Oligochaeta, Plathelminth species numbers (total 160) and diversity $\mathrm{H}^{\prime}$ (total 3.52) are exceptionally high (Tables $2,3,5$ ).

\section{Vertical pattern}

Depending on the type of sediment, the uppermost 20 to $170 \mathrm{~cm}$ of sediment were sampled (see "Sampling"). All of the samples contained meiofauna. A lower meiofaunal limit was not found, but there are such limits in single taxa. Copepoda and Ostracoda were confined to the aerobic sediment layer, at all sites. The same is true for Plathelminthes in mud; in supralittoral "mud 99" they did not even occupy all of the oxic layer. However, in muddy sand and sheltered sand, the oxic-anoxic line is no longer a border, some species were even exclusively found in anoxic sediment (e.g. Neoschizorhynchus parvorostro). 
Table 3. Plathelminth diversity $\mathrm{H}^{\prime}$ and species richness (S). For further explanations see Table 1

\begin{tabular}{|ccccccccc|}
\hline Type of sediment & $\begin{array}{c}0 \\
\mathrm{H}^{\prime}\end{array}$ & $\begin{array}{c}1 \\
\mathrm{H}^{\prime}\end{array}$ & $\begin{array}{c}10 \\
\mathrm{H}^{\prime}\end{array}$ & $\begin{array}{c}50 \\
\mathrm{H}^{\prime}\end{array}$ & $\begin{array}{c}90 \\
\mathrm{H}^{\prime}\end{array}$ & $\begin{array}{c}99 \\
\mathrm{H}^{\prime}\end{array}$ & $\begin{array}{c}\text { All heights } \\
\mathrm{H}^{\prime}\end{array}$ \\
\hline Mud & .38 & .50 & .58 & 1.35 & 2.24 & 2.23 & 2.22 & 36 \\
Muddy sand & 1.81 & 2.27 & 2.70 & 2.60 & 1.88 & 2.37 & 3.59 & 57 \\
Sheltered sand & 2.35 & 2.70 & 2.24 & 2.71 & 2.65 & 2.41 & 3.65 & 89 \\
Exposed sand & 1.03 & .60 & .92 & 1.79 & 2.21 & 1.65 & 1.74 & 41 \\
All sediments & & & & & & & & \\
H' & 2.43 & 1.87 & 2.29 & 3.15 & 3.21 & 3.23 & 3.52 & 160 \\
\hline
\end{tabular}

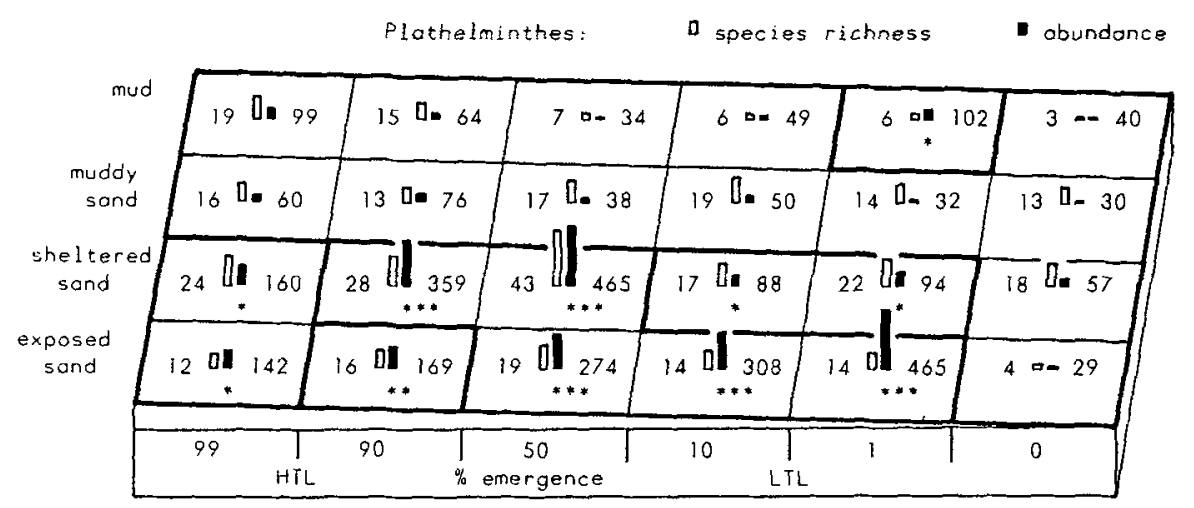

Fig. 12. Plathelminth abundance (right numbers, individuals per $10 \mathrm{~cm}^{2}$ of surface area) and species richness (left numbers, species per $10 \mathrm{~cm}^{2}$ of surface area). Abundance does not significantly differ between fiedls with the same number of asterisks, but is significantly higher in fields with a higher number of asterisks (U-test, $\mathrm{p} \leq 5 \%$ )

In mud and muddy sand, Nematoda are most abundant in the surface layer, and abundance decreases downwards independent of the oxic-anoxic border. In supralittoral sheltered sand and in exposed sand, Nematoda reach highest abundance in a deeper layer of the sediment.

The ground water level of the beaches showed no influence on the vertical pattern of most taxa. Oligochaeta, however, were not found below ground water level, while it is most attractive to some small polychaete species. Summarizing the above, the sediment depth occupied by a single meiofaunal taxon may vary between few millimeters and more than $1.5 \mathrm{~m}$. Accordingly, relating abundance to the occupied sediment volume instead of surface area results in significant differences. Related to the surface area, Copepoda are most abundant in sheltered and exposed sand. But since they only occupy the thin oxic layer of mud and muddy sand, they are more abundant there, when related to sediment volume. In Plathelminthes the situation is similar (Fig. 13). In all cases, we defined the "occupied sediment volume" as the volume of all coherent horizontal sediment layers which together contain at least $95 \%$ of the specimens of the respective taxon. 

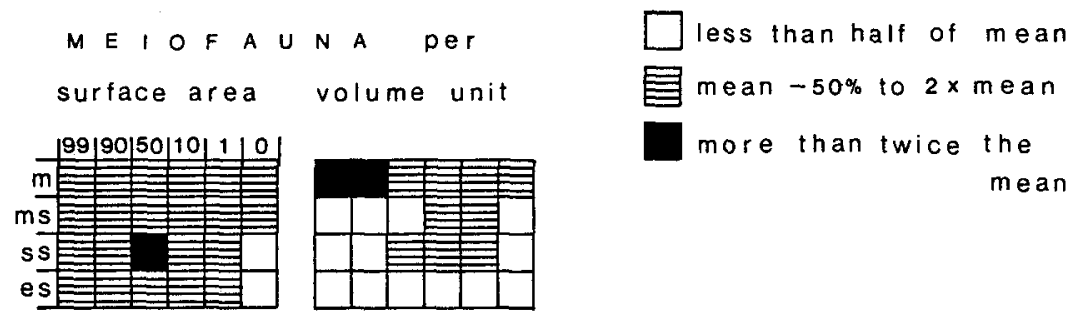

N E M A

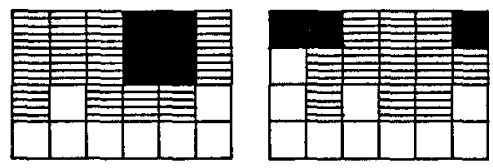

C O P E P O D A

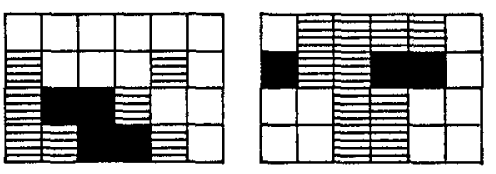

P L A T H E L M I N T H E S

O L I G O C H A E T A
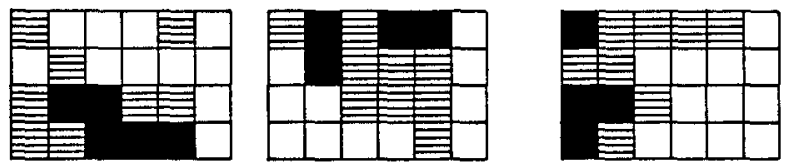

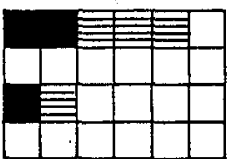

Fig. 13. Meiofaunal abundance related to surface area (left) and the occupied sediment volume (right), relative scales. m mud, ms muddy sand, ss sheltered sand, es exposed sand, $0,1,10,50,90$, 99: percentages of tidal emergence

\section{Faunal affinities}

In general, the species composition gradually changes along the tidal gradient and only few species were restricted to a single site. However, there are striking differences in the degree of faunal affinities between sites as well as between taxa. Using Sørensen's index the species composition is compared disregarding the proportion of specimens taken by a species. Renkonen's index evaluates the proportion of every species and, thus, emphasizes abundant species.

The faunal similarity of Plathelminthes, Polychaeta, Oligochaeta, and all macrofauna between every pair of sites in each of the sediment types was evaluated and arranged in Figures 15 and 16. Patterns of high and low similarities (dark and white patches, respectively) can be analysed using test hypotheses as shown in Figure 14. If there is a

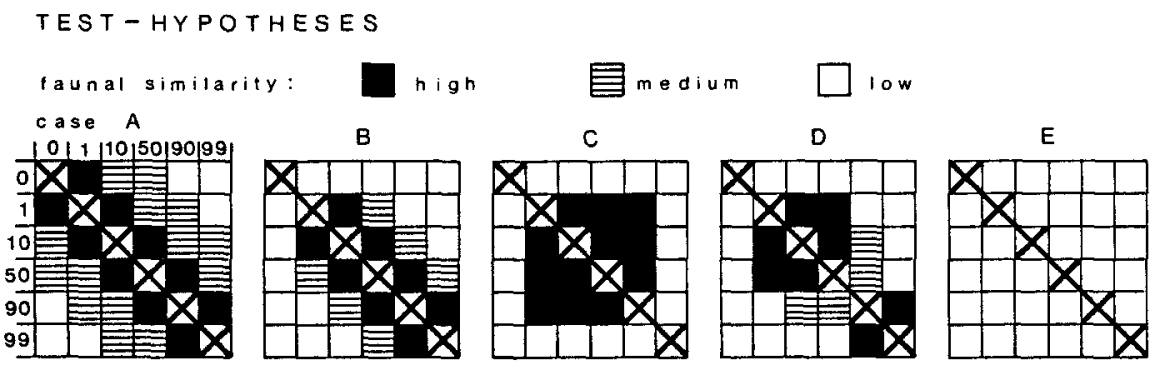

Fig. 14. Some test-hypotheses of faunal similarity. For further explanations see text 
regular faunal gradient with neighbouring sites being most similar, and a decreasing similarity with increasing distance, a pattern like case A in Figure 14 is expected. Case B gives the type of faunal gradient that is truncated at one side (" 0 " in case B). However, such regular gradients were scarcely found. Instead, there are often patches of high similarity clearly separated from neighbouring sites. There may be a single patch (Fig. 14, case C), or there may be 2 (or more) patches (Fig. 14, case D). Finally, there could be no gradient at all, every site being inhabited by a unique set of species (case E).

Looking at the real patterns (Figs 15,16), all but the latter type can be found more or less distinct. Plathelminthes form relatively regular gradients (Fig. 15), but there are patches of high dominant identity (Fig. 16). In the other taxa, gradients are difficult to detect at all. While the species composition shows clear high similarity spots in many cases, these tend to disappear when the proportion of specimens is considered. Thus, the species composition is quite similar in large areas, but the identicality of dominants is rather low.

The faunal similarity of neighbouring sites may be used to look for faunal boundaries. Mean high tide level (MHTL) and mean low tide level (MLTL) might be such ecological demarcations. Concerning MLTL (between sites " 1 " and "10") there is no hint of a faunal boundary. On the other hand, faunal similarity is often exceptionally high between these sites. Regarding MHTL (between the " 90 " and " 99 ". sites) the situation is similar, and there is also no other line that could be a general faunal boundary.

Concerning the 4 types of sediment, there seems to be a bordering line between mud and muddy sand on the one hand, and sheltered and exposed sand on the other (Fig. 17). However, this is only true for meiofauna, whereas macrofauna tends to show a more regular gradient.

\section{DISCUSSION}

\section{Abundance in late summer compared to other seasons}

This study describes the abundance pattern of meio- and macrobenthos in August/ September 1986 (late summer conditions). When Schmidt $(1968,1969)$ investigated the meiofauna of the sheltered sandy beach (i.e. sheltered sand 50 to 99 of this study) he recorded highest abundance in summer. With a delay of some weeks, the annual course of meiofaunal abundance follows the course of temperature. This seems to be typical for beaches as well as intertidal sand flats of the island of Sylt (Schmidt, 1968, p. $759 \mathrm{f}$ ). However, in supralittoral mud sites the situation is opposite. Sites that are subject to desiccation show highest meiofaunal abundance in autumn, spring, or even winter (Armonies, 1986, 1987; Hellwig, 1987). Thus, comparing the supralittoral 'mud 99' to the supralittoral sand sites means comparing annual maximum abundances to annual minimum values. It is doubtful, therefore, that the significant differences found in late summer are present throughout the year.

When Armonies (1986) compared the meiofauna of supralittoral salt marshes to other habitats of the island of Sylt, he found only slight changes in the proportion of major taxa along the tidal gradient. From all available data, Nematoda seemed to be the dominant taxon all over the intertidal zone. Including exposed beaches of the present study, it is shown that this is not the case. Exposed beaches are numerically dominated by Copepoda, at least in summer. According to Schmidt (1968), the proportion of taxa 

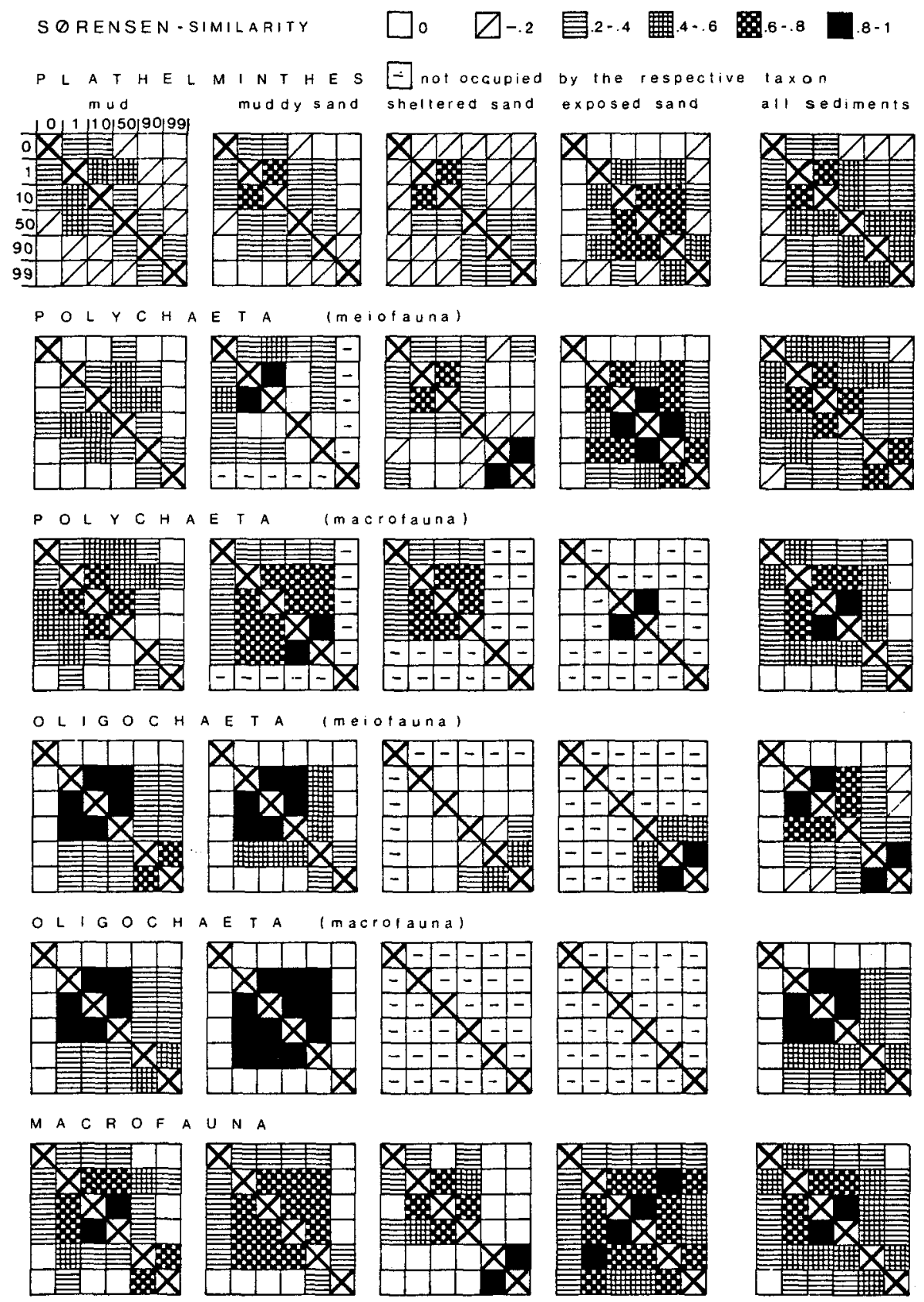

Fig. 15. Sørensen-similarity of faunal composition between the sites of each sediment type and when all sediment types are united. $0,1,10,50,90,99$ : height of sampled sites in terms of the percentage tidal emergence 


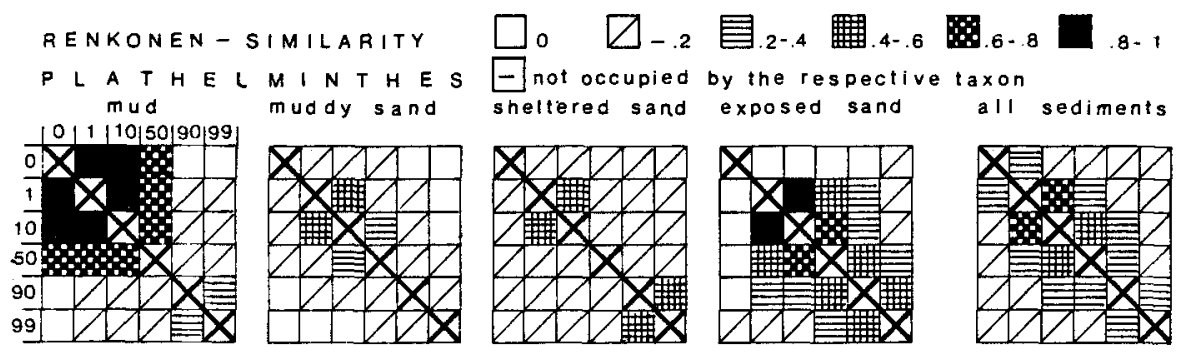

POLYCHAETA (meiofauna)
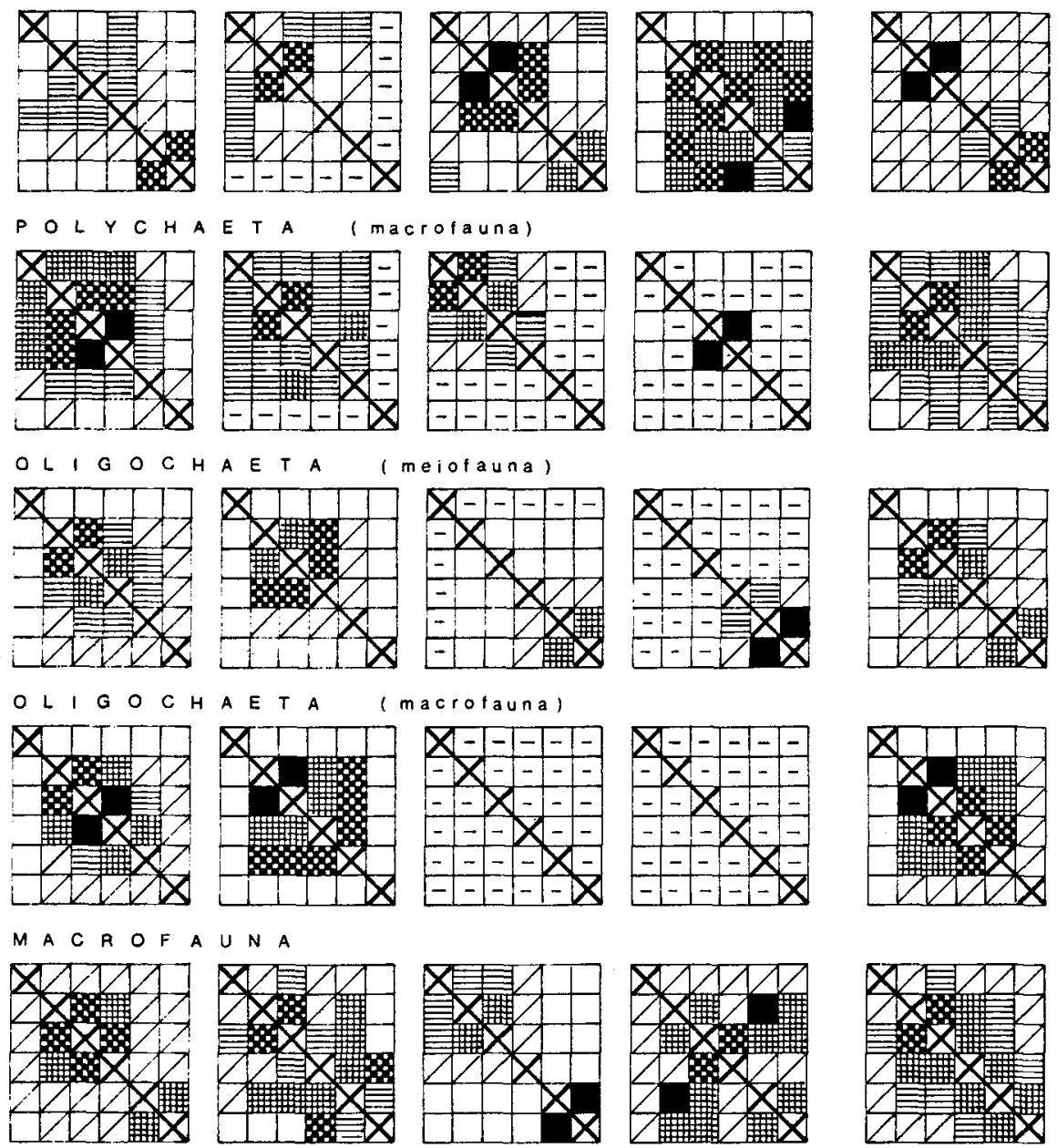

Fig. 16. Renkonen-similarity of faunal composition between the sites of each sediment type and when all sediment types are united. 0,1, 10, 50, 90, 99: height of sampled sites in terms of the percentage tidal emergence 


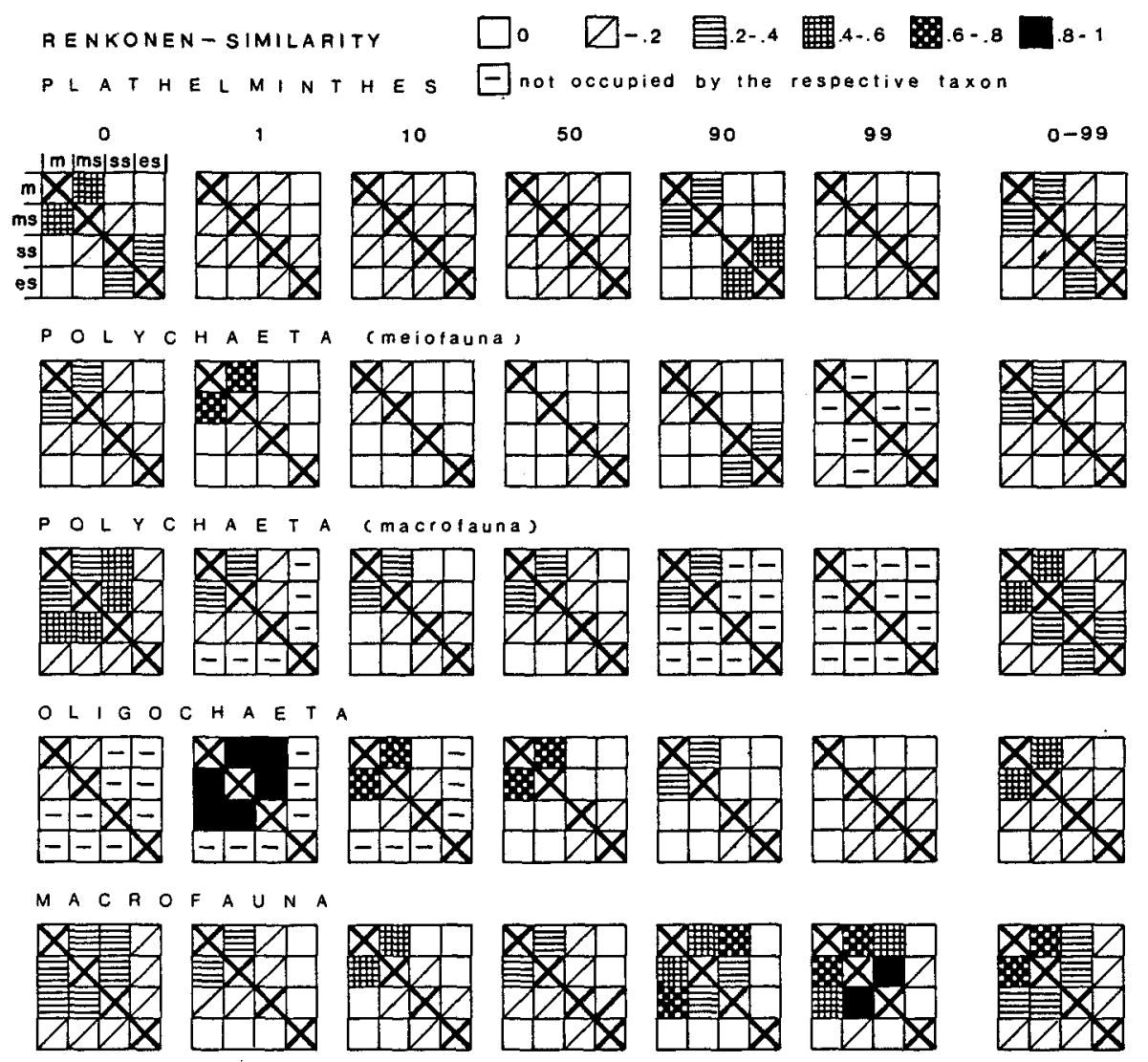

Fig. 17. Renkonen-similarity between the sediment types of every height level, and when all height levels are united (0-99). m mud, ms muddy sand, ss sheltered sand, es exposed sand

remains fairly constant all over the year. Dominance of Nematoda in mud and Copepoda in more exposed sand may therefore be regarded as a general feature. But there are at least 2 exceptions to the rule of constant proportions of taxa. (1) Tardigrada show strong annual changes in abundance and, accordingly, in the proportion of meiofauna. These animals live in the uppermost layers of rather clean sand. When this sand is subject to desiccation in summer, abundance of Tardigrada may strongly decrease. Indeed, Tardigrada were scarcely found during this study and therefore not explicitly mentioned. However, according to Schmidt (1968, p. 772) Tardigrada may account for up to $36 \%$ of all meiofauna in some beaches. (2) Desiccation also causes changes in meiofaunal taxonomic proportions observed in supralittoral salt marshes (Armonies, 1986). In addition, desiccation may be the main cause keeping the marine macrofaunal organisms out of supralittoral sites. While eulittoral sediment remains rather moist during low tide, supralittoral sand may become quite dry, and in muddy sand as well as sheltered sand, MHTL marks a significant decrease in macrofaunal abundance (cf. Fig. 2). 
Table 4. List of macrofauna species and abundances (individuals per $100 \mathrm{~cm}^{2}$ ). Asterisks (*) indicate that the same species also occurs in meiofaunal samples. $m$ mud, ms muddy sand, ss sheltered sand, es exposed sand; 0, 1, 10, 50; 90, and 99: percentage of tidal emergence. Example: ms50:1 means muddy sand at $50 \%$ tidal emergence contained 1 individual per $100 \mathrm{~cm}^{2}$ of surface area

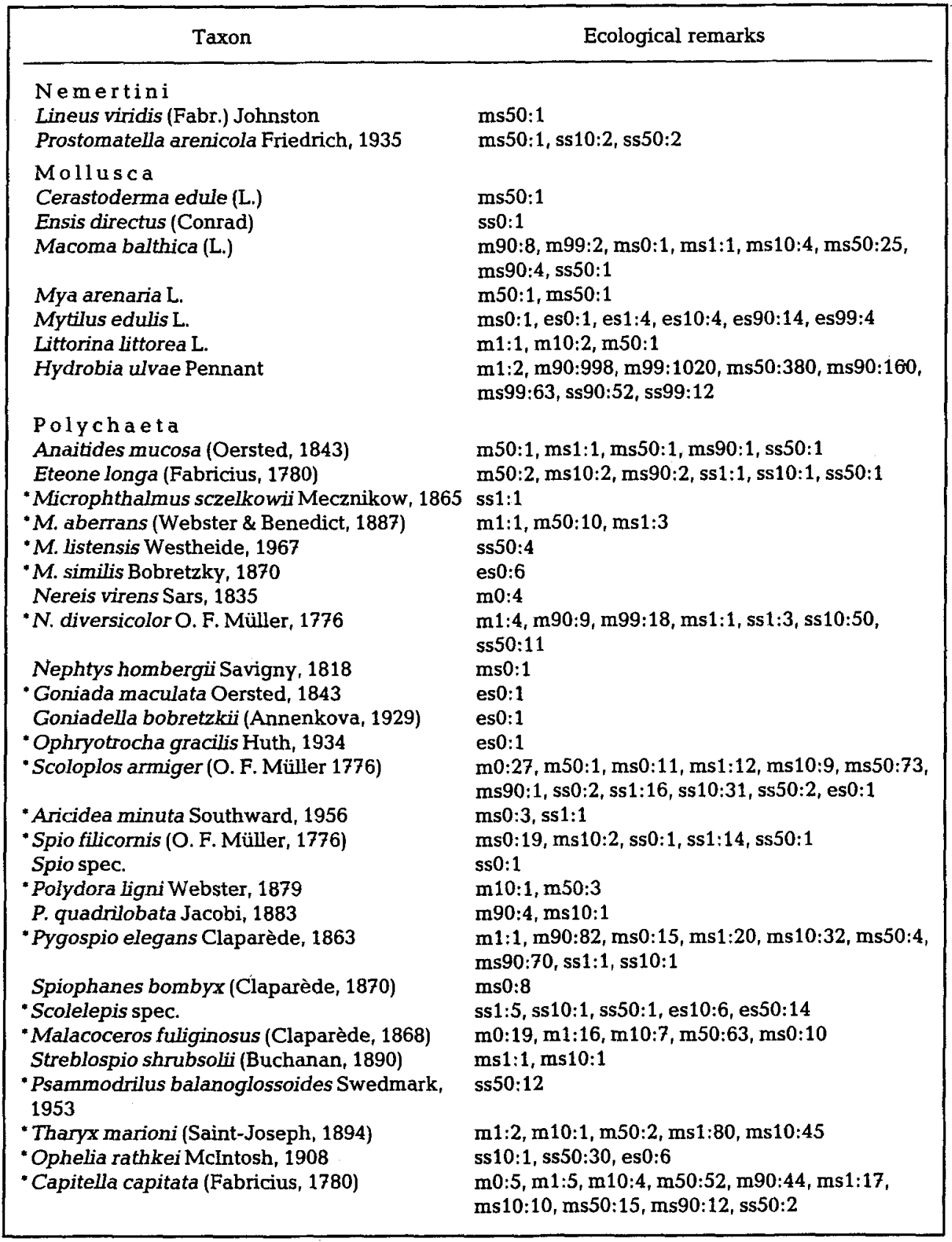


Table 4 (contd)

\begin{tabular}{|c|c|}
\hline Taxon & Ecological remarks \\
\hline $\begin{array}{l}\text { - Heteromastus filiformis (Claparède, 1864) } \\
\text { Arenicola marina (Linné, 1758) } \\
\text { Lanice conchilega (Pallas, 1766) } \\
\text { - Manayunkia aestuarina (Bourne, 1883) }\end{array}$ & $\begin{array}{l}\mathrm{m} 1: 5, \mathrm{~m} 10: 2, \mathrm{~m} 50: 24, \mathrm{~ms} 1: 16, \mathrm{~ms} 10: 4, \mathrm{~ms} 50: 1 \\
\mathrm{~ms} 90: 3,(\mathrm{~ms} 1-50, \mathrm{ss} 1-50) \\
\mathrm{m} 1: 1, \mathrm{~ms} 0: 1 \\
\mathrm{~m} 90: 74, \mathrm{~m} 99: 10\end{array}$ \\
\hline $\begin{array}{l}\text { Oli g o c h a e t a } \\
\text { "Paranais litoralis (Müller, 1784) } \\
\text { "Tubificoides benedii (d'Udekem, 1855) } \\
\text { "T. pseudogaster (Dahl, 1960) } \\
\text { "Tubifex costatus (Claparède, 1863) } \\
\text { "spec. } 1 \\
\text { "spec. } 2 \\
\text { "spec. } 3 \\
\text { "Marionina argentea (Michaelsen, 1889) } \\
\text { "M. spicula (Leuckhart, 1847) } \\
\text { " Lumbricillus enteromorphae v. Bülow, } 1957 \\
\text { "L. knoellneri Nielsen \& Christensen, } 1959\end{array}$ & $\begin{array}{l}\mathrm{m} 90: 7 \\
\mathrm{~m} 1: 38, \mathrm{~m} 10: 87, \mathrm{~m} 50: 383, \mathrm{~m} 90: 135, \mathrm{~m} 99: 5, \\
\mathrm{~ms} 1: 7, \mathrm{~ms} 10: 10, \mathrm{~ms} 50: 66, \mathrm{~ms} 90: 167 \\
\mathrm{~m} 1: 397, \mathrm{~m} 10: 145, \mathrm{~m} 50: 307, \mathrm{~ms} 1: 54, \mathrm{~ms} 10: 61, \\
\mathrm{~ms} 50: 38, \mathrm{~ms} 90: 296 \\
\mathrm{~m} 90: 26, \mathrm{~m} 99: 46 \\
\mathrm{~m} 99: 28 \\
\mathrm{~m} 0: 13 \\
\mathrm{~ms} 0: 19 \\
\mathrm{~m} 90: 2 \\
\text { ss50:30 } \\
\text { m99:70, ms90:6, ms99:3 } \\
\mathrm{ms} 99: 1, \text { es99:4 }\end{array}$ \\
\hline $\begin{array}{l}\text { Crust a ce a } \\
\text { Carcinus maenas (L.) } \\
\text { Crangon crangon (L.) } \\
\text { Bodotria scorpioides (Montagu, 1804) } \\
\text { Pseudocuma longicornis (Bate, 1858) } \\
\text { Bathyporeia elegans Watkin, 1938 } \\
\text { Corophium volutator Pallas, } 1766 \\
\text { Microprotopus longimanus Chevreux, } 1887 \\
\text { Isopoda indet. } \\
\text { Isopoda Oniscoidea (terrestrial, indet.) }\end{array}$ & $\begin{array}{l}\mathrm{m} 0: 2, \mathrm{~m} 10: 8, \mathrm{~m} 50: 6, \mathrm{~ms} 0: 2, \mathrm{~ms} 1: 1 \\
\mathrm{~m} 0: 1 \\
\mathrm{~m} 0: 1 \\
\mathrm{ss} 0: 1 \\
\mathrm{ss} 0: 4 \\
\mathrm{~ms} 90: 1 \\
\mathrm{~ms} 0: 1, \mathrm{~ms} 1: 1 \\
\mathrm{~ms} 0: 9 \\
\mathrm{~ms} 99: 2\end{array}$ \\
\hline $\begin{array}{l}\text { In } \mathrm{sect} \text { a } \\
\text { Bledius arenarius Schneider }\end{array}$ & ms99:1 \\
\hline
\end{tabular}

\section{Abundance in sublittoral sand}

In this study the top 20 to $170 \mathrm{~cm}$ of sediment were sampled, but a lower boundary of meiofaunal or macrofaunal settlement was found at neither site. In exposed sand station 1 (just below MLTL) the 30 to $40 \mathrm{~cm}$ layer of the sediment was still colonized by Nematoda, Copepoda, Ostracoda, Polychaeta, and Plathelminthes. Presumably, none of these taxa could be completely recorded here. The Reineck box-corer used to collect the sublittoral samples yielded about $20 \mathrm{~cm}$ of sediment on an average. Since $40 \mathrm{~cm}$ was not sufficient to include all the fauna just below MLTL, $20 \mathrm{~cm}$ will certainly underestimate sublittoral abundace. McLachlan et al. (1977) reported meiofauna to be abundant down to at least $35 \mathrm{~cm}$ in sublittoral sand of Algoa Bay, South Africa. Thus, the significant lower abundance of both macro- and meiofauna in sublittoral sand compared to the lower eulittoral sites is at least partly due to the limited sediment depth sampled. 
Table 5. Plathelminthes, meiofaunal Polychaeta and Oligochaeta, and their abundances (individuals per $10 \mathrm{~cm}^{2}$ surface area). Asterisks (") indicate that the same species also occurs in macrofaunal samples. $m$ mud, ms muddy sand, ss sheltered sand, es exposed sand; $0,1,10,50,90,99$ : percentages of tidal emergence

\begin{tabular}{|c|c|}
\hline Taxon & Ecological remarks \\
\hline \multicolumn{2}{|l|}{ Plathelminthes } \\
\hline $\begin{array}{l}\text { A co el a } \\
\text { Aphanostoma album Dörjes, } 1968 \\
\text { Archaphanostoma agile (Jensen, 1878) } \\
\text { A. histobursalium Dörjes, } 1968 \\
\text { Praeaphanostoma rubrum Dörjes, } 1968 \\
\text { P. chaetocaudatum Dörjes, } 1968 \\
\text { Pseudaphanostoma pelophilum Dörjes, } 1968 \\
\text { P. psammophilum Dörjes, } 1968 \\
\text { Antroposthia unipora Faubel, } 1974 \\
\text { Haplogonaria syltensis Dörjes, } 1968 \\
\text { H. macrobursalia Dörjes, 1968 } \\
\text { Actinoposthia biaculeata Faubel, } 1974 \\
\text { Atriofronta polyvacuola Dörjes, 1968 } \\
\text { Paraproporus cf. diovatus Dörjes, } 1968 \\
\text { Mecynostomum auritum (M. S. Schultze, 1851) } \\
\text { Postmecynostomum pictum Dörjes, } 1968 \\
\text { Pseudmecynostomum bruneum Dörjes, 1968 } \\
\text { spec. } 1 \\
\text { spec. } 2\end{array}$ & $\begin{array}{l}\mathrm{m} 50: 3, \mathrm{~ms} 50: 2 \\
\mathrm{~ms} 0: 3, \mathrm{ss} 1: 4 \\
\mathrm{~m} 0: 36, \mathrm{~m} 1: 91, \mathrm{~m} 10: 41, \mathrm{~m} 50: 22, \mathrm{~ms} 0: 15 \\
\mathrm{~ms} 0: 2 \\
\mathrm{~ms} 99: 14 \\
\mathrm{~m} 90: 1, \mathrm{~m} 99: 5, \mathrm{~ms} 10: 2 \\
\mathrm{ss} 10: 1, \mathrm{ss} 50: 44 \\
\mathrm{ss} 90: 26, \mathrm{ss} 99: 5 \\
\text { ss0:13, ss1:9, ss10:1, es } 0: 17 \\
\text { ss50:11 } \\
\text { es } 1: 1, \mathrm{es} 10: 13, \text { es} 50: 25, \text { es} 90: 8 \\
\text { ss50:142 } \\
\text { ss0:11 } \\
\mathrm{m} 90: 1, \mathrm{~m} 99: 1 \\
\mathrm{~m} 1: 1, \mathrm{~m} 10: 2, \mathrm{~ms} 0: 1, \mathrm{~ms} 10: 1, \mathrm{ss} 1: 6, \mathrm{ss} 50: 8 \\
\mathrm{~ms} 10: 1, \mathrm{ss} 50: 1 \\
\mathrm{~ms} 0: 1, \mathrm{~ms} 1: 1, \mathrm{~ms} 10: 3 \\
\mathrm{~ms} 90: 3\end{array}$ \\
\hline $\begin{array}{l}\text { Ca te n u li d a } \\
\text { Retronectes cf. sterreri Faubel, } 1976 \\
\text { spec. } 1 \\
\text { spec. } 2\end{array}$ & $\begin{array}{l}\mathrm{ss} 0: 2 \\
\mathrm{~ms} 10: 1 \\
\mathrm{ss} 50: 1\end{array}$ \\
\hline $\begin{array}{l}\text { Prol e c it h o p h or a } \\
\text { Archimonotresis limophila Meixner, } 1938 \\
\text { Plagiostomidae, spec. } 1 \\
\text { Plagiostomidae, spec. } 2 \\
\text { Scleraulophorus cephalatus Karling, } 1940\end{array}$ & $\begin{array}{l}\text { ms0:1, ms } 1: 1, \text { ms } 10: 1 \\
\text { ss } 1: 1 \\
\text { ms } 1: 1, \text { ss } 1: 1 \\
\text { es50:4 }\end{array}$ \\
\hline $\begin{array}{l}\text { Ma cr o s t o m id a } \\
\text { Macrostomum balticum Luther, } 1921 \\
\text { M. pusillum Ax, } 1951 \\
\text { Antromacrostomum armatum Faubel, } 1974 \\
\text { Myozona purpurea Faubel, } 1974 \\
\text { Microstomum papillosum Graff, } 1882 \\
\text { Microstomum spiculifer Faubel, } 1974\end{array}$ & $\begin{array}{l}\text { m99:33 } \\
\text { m90:6, m99:1, ms90:32, ms } 99: 1 \\
\text { es99:3 } \\
\text { ss } 90: 3 \\
\text { es } 0: 7 \\
\text { ms } 10: 1 \text {, ss } 1: 5, \text { ss } 10: 5, \text { ss } 50: 3, \text { ss } 90: 1, \text { ss } 99: 1, \\
\text { es } 1: 7, \text { es } 10: 3\end{array}$ \\
\hline $\begin{array}{l}\text { Microstom um spec. } \\
\text { Paromalostomum fusculum Ax, } 1952 \\
P . \text { dubium (De Beauchamp, 1927) } \\
\text { P. cf. proceracauda Pawlak, } 1969\end{array}$ & $\begin{array}{l}\mathrm{ms} 0: 1, \mathrm{~ms} 1: 1, \mathrm{ss} 0: 1 \\
\mathrm{ss} 1: 2 \\
\mathrm{~ms} 50: 2, \mathrm{ss} 1: 2, \mathrm{ss} 10: 1 \\
\mathrm{ss} 50: 1, \mathrm{ss} 90: 6, \mathrm{ss} 99: 1\end{array}$ \\
\hline $\begin{array}{l}\text { Pros e r i a ta } \\
\text { Monocelis lineata O. F. Müller, } 1774 \\
\text { M. fusca Oersted, } 1843 \\
\text { Mesoda septentrionalis Sopott, } 1972\end{array}$ & $\begin{array}{l}\text { m99:7, ms99:2, ss90:1 } \\
\text { m50:3, m90:1, m99:1, ms50:3, ms90:12 } \\
\text { ss99:1, es99:1 }\end{array}$ \\
\hline
\end{tabular}


Table 5 (contd)

Archilopsis inopinata Martens, Curini-Galetti mi50:1, m90:3, m99:5

\& Puccinelli, 1987

A. unipunctata Fabricius, 1826

Monocelididae spec.

Archimonocelis spec.

Coelogynopora axi Sopott, 1972

Carenscoilia bidentata Sopott, 1972

Cirrifera cirnifera Sopott, 1972

Coelogynoporidae, spec. 1

Coelogynoporidae, spec. 2

Itaspiella helgolandica (Meixner, 1938)

Otoplanella schulzi $(\mathrm{Ax}, 1951)$

Notocaryoplanella glandulosa (Ax, 1951)

Bulbotoplana acephala Ax, 1956

Otoplanidae indet.

Parotoplana capitata Meixner, 1938

P. papii Ax, 1956

Kataplana germanica (Meixner in Ax, 1951)

Praebursoplana reisingeri Ax, 1956

Parotoplanidae, spec. 1

Parotoplanidae, spec. 2

Parotoplanidae, spec. 3

Nematoplana coelogynoporoides Meixner, 1938

Polystyliphora filum Ax, 1958

ms99:7, ss $1: 2$, ss 10:1, ss50:9

$\mathrm{m} 1: 3, \mathrm{~ms} 10: 1, \mathrm{~ms} 50: 4$

ss0:4

ss $0: 5$, ss $50: 1$, es $1: 1$

ss1:5

ss $1: 8$, es 10:1

ss $0: 3$, ss 10:5, ss50:3, ss90:2, es $0: 2$, es99:2

ss1:1, ss10:1, ss50:1, ss99:2

es 10:1, es50:1

ss90:5, ss99:3, es90:16, es99:73

es 10:6, es50:4

ss $1: 2$, ss10:1, ss50:27, es90:4, es99:8

es $1: 4$, es99:3

ss50:4, ss90:16, ss99:2

ss $90: 2$

ss $0: 7$, ss $1: 2$, es $0: 2$

ss90:34, ss99:6, es10:8, es50:19, es90:40, es99:16

ss90:57, ss99:2, es10:5, es50:2

ss0:1

es $1: 4$

ss0:3, ss50:40, ss90:53, ss99:6, es 1:413, es $10: 249$, es50:151, es90:37, es99:17

ss50:9

Typhloplanoida

Proxenetes ampullatus $\mathrm{Ax}_{1} 1971$

P. intermedius Den Hartog, 1966

$P$. quinquespinosus $\mathrm{Ax}, 1971$

P. segmentatus Den Hartog, 1965

P. simplex Luther, 1948

$P$. tenuispinosus Ehlers, 1974

P. trigonus Ax, 1960

Mariplanella frisia Ax \& Heller, 1970

Messoplana elegans (Luther, 1943)

Ptychopera westbladi (Luther, 1943)

Trigonostomum breitfussi (Graff, 1905)

Trigonostomidae, spec. 1

Ciliopharyngiella intermedia Ax, 1952

Adenopharynx mitrabursalis Ehlers, 1972

Anthopharynx sacculipenis Ehlers, 1972

Aulopharynx aestuarius Ehlers, 1972

Doliopharynx geminocirro Ehlers, 1972

Proceropharynx littoralis Ehlers, 1972

Tensopharynx inermis Ehlers, 1972

Solenopharyngidae, spec. 1

$\mathrm{m} 50: 2$

$\mathrm{m} 50: 1, \mathrm{~m} 90: 1$

$\mathrm{m} 0: 3$

$\mathrm{m} 1: 1, \mathrm{~m} 50: 1, \mathrm{~m} 90: 6, \mathrm{~m} 99: 1, \mathrm{~ms} 1: 1, \mathrm{~ms} 10: 1$, ms90:1

m99:1

ss $50: 3$

ss 10:2

ss50:24, ss90:1, es 1:3, es 10:1, es90:2

$\mathrm{ms} 90: 6$

m $90: 3, \mathrm{~m} 99: 1$

$\mathrm{m} 10: 1$

$\mathrm{ms} 1: 11, \mathrm{~ms} 10: 3, \mathrm{ss} 90: 3$

ss90:20, ss99:3, es1:12, es10:11, es50:24,

es90:12

m99:1, ms90:1, ss50:1

ss90:13

ss50:2

ss50:1

ms99:2, ss50:2, es50:1, es90:2

ss50:2

es50:3

Solenopharyngidae, spec. $2 \quad$ es99:1 
Table 5 (contd)

\begin{tabular}{|c|c|}
\hline Taxon & Ecological remarks \\
\hline Haloplanella longatuba Ax \& Heller, 1970 & ss90:7, ss99:1 \\
\hline H. minuta Luther, 1946 & $\mathrm{~m} 99: 1$ \\
\hline H. hamulata Ehlers, 1974 & ss50:1 \\
\hline Haloplanella spec. & ss99:3 \\
\hline Pratoplana salsa Ax, 1960 & $\mathrm{~m} 90: 7, \mathrm{~m} 99: 14, \mathrm{~ms} 0: 1$ \\
\hline P. galeata Ehlers, 1974 & ss $90: 15$, ss $99: 14$ \\
\hline Typhloplaninae, spec. 1 & ms0:1 \\
\hline Promesostoma bipartitum Ax, 1956 & es99:1 \\
\hline P. caligulatum Ax, 1952 & m90:4 \\
\hline P. gracilis Ax, 1951 & $\mathrm{~ms} 1: 1, \mathrm{~ms} 10: 7$ \\
\hline P. karlingi Ehlers, 1974 & $\mathrm{~m} 1: 4, \mathrm{~m} 10: 1, \mathrm{~m} 50: 2, \mathrm{~ms} 1: 3, \mathrm{~ms} 10: 4$ \\
\hline P. marmoratum M. Schultze, 1851 & $\mathrm{~m} 90: 1, \mathrm{~ms} 1: 1, \mathrm{~ms} 50: 3$ \\
\hline P. meixneri Ax, 1951 & ms0:1, ms50:2, ss $1: 7$, ss $10: 9$, ss $50: 10$, es $1: 1$ \\
\hline P. rostratum $\mathrm{Ax}, 1951$ & $\operatorname{ms} 90: 2$ \\
\hline P. serpentistylum Ax, 1952 & ss50:5 \\
\hline Brinkmanniella macrostomoides Luther, 1948 & ss50:1, ss90:2, ss99:1 \\
\hline Coronhelmis lutheri Ax, 1951 & ms99:1 \\
\hline Moevenbergia oculofagi nom. nud. & $\mathrm{m} 0: 1, \mathrm{~ms} 0: 1, \mathrm{~ms} 1: 2, \mathrm{~ms} 10: 1$ \\
\hline Adenorhynchus balticus Meixner, 1938 & ss90:2, es50:1 \\
\hline Litucivis serpens Ax \& Heller, 1970 & ss50:2, ss90:1, ss99:1 \\
\hline Listea simplex Ax \& Heller, 1970 & ss $90: 3$, ss $99: 1$, es $1: 3$, es $10: 3$, es $50: 5$, es $90: 1$ \\
\hline Petaliella spiracauda Ehlers, 1974 & ss $50: 3$ \\
\hline Lonchoplanella axi Ehlers, 1974 & ss90:3, ss99:19 \\
\hline Promesostomidae, spec. 1 & $\operatorname{ms50:1}$ \\
\hline Promesostomidae, spec. 2 & $\mathrm{~ms} 90: 1$ \\
\hline \multicolumn{2}{|l|}{ Kalyptorhynchia } \\
\hline Acrorhynchides robustus (Karling, 1931) & $\mathrm{m} 90: 1, \mathrm{~ms} 90: 9$ \\
\hline Gyratrix hermaphroditus Ehrenberg, 1831 & ms0:1, ss $1: 4$, ss $10: 14$, ss $50: 38$ \\
\hline Scanorhynchus forcipatus Karling, 1955 & $\mathrm{~ms} 0: 1$ \\
\hline Neopolycystis tridentata Karling, 1955 & ss90:7, ss99:10, es $50: 2$, es $90: 2$ \\
\hline Utelga scotica Karling, 1954 & ms50:1 \\
\hline Parautelga bilioi Karling, 1964 & m99:14 \\
\hline Marirhynchus longasaeta Schilke, 1970 & ss90:1, es $50: 7$ \\
\hline $\begin{array}{l}\text { Cystiplana paradoxa Karling, } 1964 \\
\text { Nigerrhynchus opisthoporus Schilke, } 1970\end{array}$ & $\begin{array}{l}\text { ss } 90: 55 \text {, ss } 99: 49 \text {, es } 10: 1 \text {, es } 50: 12 \text {, es } 90: 9 \text {, es } 99: 3 \\
\text { es } 50: 3\end{array}$ \\
\hline Psammorhynchus tubulipenis Meixner, 1938 & ss $1: 2$, ss $10: 1$, ss $50: 4$ \\
\hline Cicerina brevicirrus Meixner, 1928 & ms10:2, ms50:6, ms90:1 \\
\hline C. remanei Meixner, 1928 & ss $1: 1$, ss $10: 1$ \\
\hline C. tetradactyla Giard, 1904 & ms $90: 4, s s 50: 2$ \\
\hline Zonorhynchus salinus Karling, 1952 & m99:3 \\
\hline Z. seminascatus Karling, 1956 & $\mathrm{~m} 90: 11, \mathrm{~m} 99: 4, \mathrm{~ms} 1: 4, \mathrm{~ms} 10: 4, \mathrm{~ms} 50: 1, \mathrm{~ms} 90: 4$ \\
\hline Elvertia krusei Noldt, 1987 & es $10: 4$, es50:6, es90:15 \\
\hline Eukalyptorhynchia, spec. 1 & ss99:3 \\
\hline Eukalyptorhynchia, spec. 2 & $\mathrm{~m} 99: 2$ \\
\hline Placorhynchus cf. echinulatus Karling, 1947 & $\mathrm{~m} 1: 2$ \\
\hline Gnathorhynchidae, spec. 1 & ms50:1 \\
\hline Proschizorhynchus gullmarensis Karling, 1950 & ms99:4, ss90:15, ss99:21, es90:5, es99:16 \\
\hline P. helgolandicus L'Hardy, 1965 & es $1: 5$ \\
\hline Schizorhynchoides aculeatus L'Hardy, 1963 & ss50:1, ss99:1 \\
\hline Schizochilus choriurus Boaden, 1963 & ss $1: 1, \operatorname{ss} 50: 8, \operatorname{ss} 90: 1$ \\
\hline
\end{tabular}


Table 5 (contd)

\begin{tabular}{|c|c|}
\hline Taxon & Ecological remarks \\
\hline $\begin{array}{l}\text { Neoschizorhynchus parvorostro Ax \& Heller, } \\
1970\end{array}$ & $\mathrm{~ms} 1: 1, \mathrm{~ms} 10: 6, \mathrm{~ms} 50: 4$ \\
\hline Schizorhynchidae, spec. 1 & es $50: 3$, es $90: 9$ \\
\hline Carcharodorhynchus listensis Schilke, 1970 & ss50:3 \\
\hline Carcharodorhynchus spec. & ss $90: 1$ \\
\hline Thylacorhynchus caudatus Meixner, 1928 & ss $50: 1$, es $1: 6$, es $10: 1$, es $50: 1$, es $90: 1$ \\
\hline T. arcassonensis De Beauchamp, 1927 & $\mathrm{~ms} 99: 4$ \\
\hline Karkinorhynchus listensis Schilke, 1970 & ss10:1 \\
\hline K. primitivus Meixner, 1928 & es $10: 1$, es $50: 2$ \\
\hline K. purpureus Schilke, 1970 & es $1: 1$ \\
\hline Cheliplana boadeni Schilke, 1970 & ss $50: 10$ \\
\hline C. remanei (Meixner, 1928) & $\mathrm{ms} 50: 2, \mathrm{~ms} 99: 2, \mathrm{ss} 1: 9, \mathrm{ss} 10: 9$ \\
\hline Cheliplanilla caudata Meixner, 1938 & $\mathrm{~ms} 10: 4, \mathrm{~ms} 50: 3$ \\
\hline Cheliplanilla spec. & sso:1 \\
\hline Diascorhynchus serpens Karling, 1949 & $\mathrm{~ms} 50: 1, \mathrm{~ms} 99: 6$ \\
\hline D. rubrus Boaden, 1963 & ss50:9 \\
\hline \multicolumn{2}{|l|}{$\begin{array}{l}\text { D a l y elli o i d a } \\
\text { Bresslauilla relicta Reisinger, } 1929\end{array}$} \\
\hline & $\begin{array}{l}\mathrm{m} 10: 1, \mathrm{~m} 90: 18, \mathrm{~m} 99: 2, \mathrm{~ms} 1: 1, \mathrm{~ms} 10: 5, \mathrm{~ms} 50: 1 \\
\mathrm{~ms} 90: 3, \mathrm{ss} 1: 1, \mathrm{ss} 10: 15\end{array}$ \\
\hline Bresslauilla spec. 1 & ss0:1, ss50:6, es $1: 3$ \\
\hline Bresslauilla spec. 2 & ss $0: 1$ \\
\hline Halammovortex macropharynx Meixner, 1938 & $\mathrm{~ms} 90: 2$ \\
\hline H. nigrifrons Karling, 1935 & $\mathrm{~m} 10: 1$ \\
\hline Provortex balticus Schultze, 1851 & m99:1 \\
\hline P. karlingi Ax, 1951 & ms99:1 \\
\hline P. psammophilus Ax, 1951 & ms99:1, ss50:13 \\
\hline P. tubiferus Luther, 1948 & m90:1 \\
\hline Pogaina kinnei Ax, 1970 & $\mathrm{~ms} 1: 1, \mathrm{~ms} 10: 1, \mathrm{ss} 1: 20, \mathrm{ss} 10: 20, \mathrm{ss} 50: 3$ \\
\hline Balgetia semicirculifera Luther, 1962 & ms90:1 \\
\hline Hangethellia calceifera Karling, 1940 & ms99:5, ss50:1 \\
\hline Provorticidae, spec. 1 & ms90:1 \\
\hline Provorticidae, spec. 2 & ss0:1 \\
\hline Provorticidae, spec. 3 & ss0:1 \\
\hline \multirow{2}{*}{\multicolumn{2}{|c|}{$\begin{array}{l}\text { Polychaeta } \\
\text { Nereiomorpha }\end{array}$}} \\
\hline & \\
\hline Pisione remota (Southern, 1914) & es $1: 2$ \\
\hline Hesionides arenaria Friedrich, 1937 & ss90:140, ss99:6, es50:176, es90:16, es99:4 \\
\hline •Microphthalmus sczelkowii Mecznikow, 1865 & $\mathrm{~m} 0: 4, \mathrm{~ms} 0: 5, \mathrm{~ms} 50: 8, \mathrm{ss} 0: 1, \mathrm{ss} 1: 8, \mathrm{ss} 10: 8$ \\
\hline •M. aberrans (Webster \& Benedict, 1887) & $\mathrm{m} 1: 4, \mathrm{~m} 50: 4, \mathrm{~ms} 1: 8, \mathrm{~ms} 10: 2$ \\
\hline •M. listensis Westheide, 1967 & ss $0: 3$, ss50:22 \\
\hline •M. similis Bobretzky, 1870 & es0:10 \\
\hline " Nereis diversicolor O. F. Müller, 1776 & m99:2, ss10:8 \\
\hline * Goniada maculata Oersted, 1843 & $\mathrm{ss} 0: 1$ \\
\hline * Ophryotrocha gracilis Huth, 1934 & es $0: 4$ \\
\hline Parapodrilus psammophilus Westheide, 1965 & ss50:32 \\
\hline \multicolumn{2}{|l|}{ Spiomorpha } \\
\hline "Scoloplos armiger (O. F. Müller, 1776) & $\mathrm{m} 0: 6, \mathrm{~ms} 50: 8, \mathrm{ss} 10: 6$ \\
\hline "Aricidea minuta Southward, 1956 & $\begin{array}{l}\mathrm{ms} 0: 2, \mathrm{ss} 1: 2 \\
\mathrm{~ms} 0: 4, m s 1 \cdot 2, \mathrm{~ms} 10 \cdot 4, \mathrm{ss} 1: 8\end{array}$ \\
\hline $\begin{array}{l}\text { "Spio filicornis (O. F. Müller, 1766) } \\
\text { "Polydora ligni Webster, } 1879\end{array}$ & $\begin{array}{l}\mathrm{ms} 0: 4, \mathrm{~ms} 1: 2, \mathrm{~ms} 10: 4, \mathrm{ss} 1: 8 \\
\mathrm{~m} 10: 1\end{array}$ \\
\hline
\end{tabular}


Table 5 (contd)

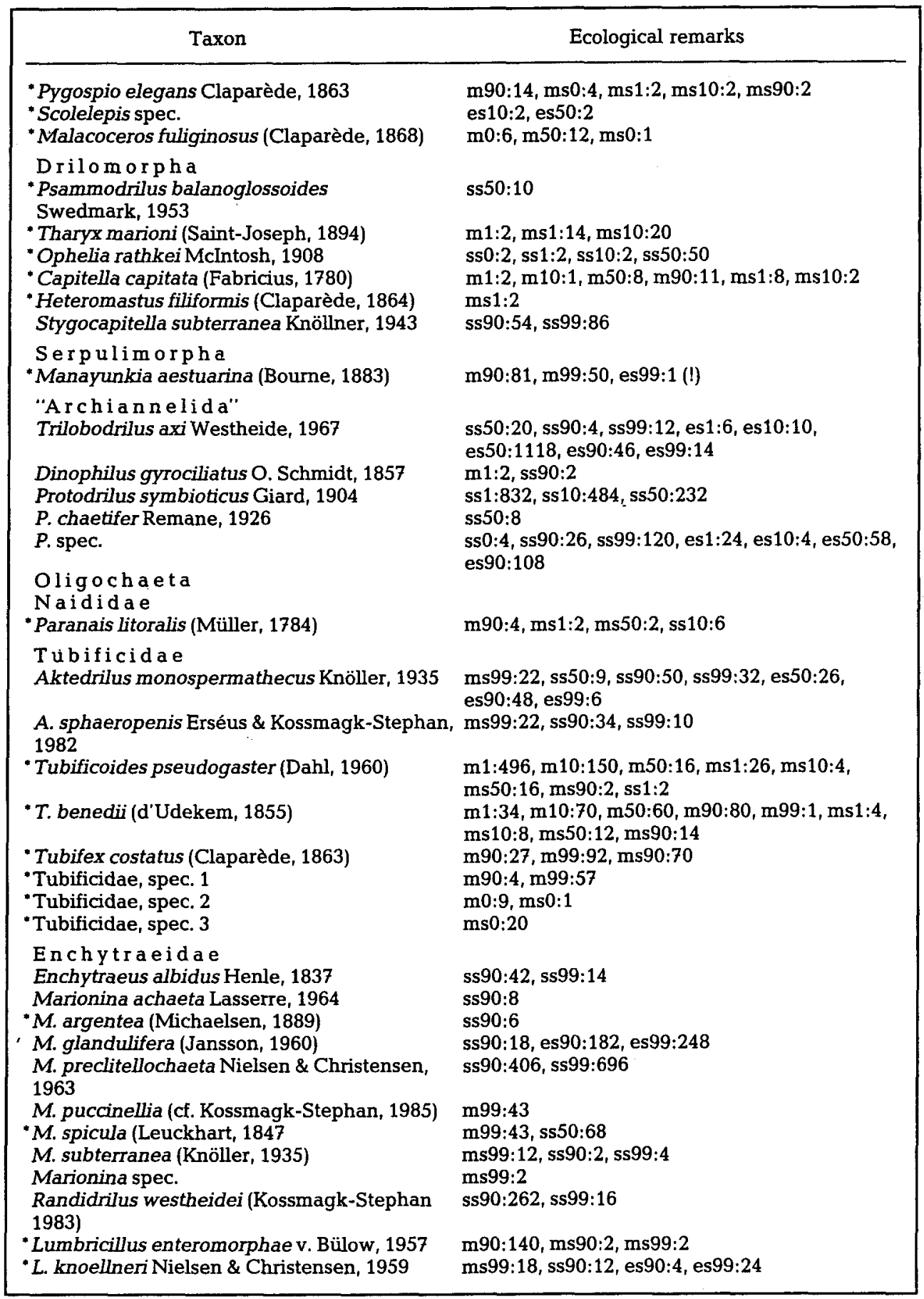




\section{Abundance related to surface area and sediment volume}

It has become standard, in recent years, to relate abundance of benthic organisms to the sediment surface area. There are some good reasons for doing so: (1) Samples are usually collected by means of tubes or metal boxes pushed into the sediment. When this device is drawn out again from the sediment, it yields a sediment column of varying height but constant surface area. (2) Many benthic organisms perform vertical migrations in the sediment. Pushing the sample corer deep enough into the sediment and relating abundance to the surface area of this core, these migrations will not influence the per surface area abundance. (3) Quite a number of processes affect the sediment column according to the surface area and independent of the sediment depth, e.g. benthic primary productivity, or mud and detritus accretion.

Abundance per surface area is well qualified to describe the economical situation of a territory. The abundance pattern given in Figures 2 to 12 describe such territories. However, these patterns are completely different in some cases, when abundance is related to the occupied sediment volume (we used the average per volume abundance of the coherent column of vertical layers that contains at least $95 \%$ of the specimens) instead of sediment surface area (Fig. 13). Plathelminthes, for instance, attain their highest per surface area abundance in sand, but the highest per volume abundance (density) is found in mud. In Copepoda and Ostracoda the situation is similar. In these taxa, the majority of species seems to be confined to oxic conditions. In contrast, because of their vertical distribution patterns, Nematoda and Oligochaeta seem to be less dependent on oxygen, and their per area and per volume patterns are not as divergent as in the former taxa (see Fig. 13).

The obvious dependence of most Plathelminthes, Copepoda, and Ostracoda on oxygenated sediment layers may easily explain why these taxa attain their highest per surface area abundance in sand: there is just more space to live in. However, since the per volume abundances are higher in mud, is mud a more favourable site?

Abundance per surface area describes the human point of view when comparing different localities. It is not neccessarily related to the living conditions of the organisms. From the point of view of, for example, a copepod specimen it is presumably beyond interest to know how many other copepods live in the sediment cores above or below. Food supply, nearest neighbour distance, and favourable factors in the small amount of sediment where it lives may be more essential. For interstitial species, factors of such a kind are presumably more related to per volume abundance than to per area abundances. Dense populations indicate beneficial conditions for life.

The macrofauna attained highest (per surface area) abundance in mud and muddy sand. Since the vertical distribution pattern of macrofauna is similar at all sites, the horizontal distribution pattern will not be very different when related to sediment volumes instead of surface area. While the (per surface area) abundance pattern of meiofauna is not very similar to the macrofauna pattern, the meio- and macrofaunal density (per volume abundance) patterns are much more similar to each other. Mud and muddy sand show highest densities, and exposed sand the least (Figs 2,13). Thus, the pattern of individual densities indicate that there are only minor differences between meio- and macrofauna. With the exception of some taxa confined to sand (e.g. Gastrotricha), conditions of life seem to be most favourable in mud and least in exposed sand 
(mud: 22 to 387 individuals per $1 \mathrm{~cm}^{3}$; muddy sand: 6 to 52 ; sheltered sand: 3 to 28 ; exposed sand 2 to 12 individuals per $1 \mathrm{~cm}^{3}$ ).

\section{Faunal affinities}

Biotic and abiotic factors gradually change along the tidal gradient. Correspondingly, the faunal composition may also change gradually, or there might be sharp boundaries (Lindroth, 1971; Cassie, 1972). Such boundaries in faunal composition are desired for the recognition of communities (e.g. Thorson, 1957) but they are not imperative (Mills, 1969).

In this study, no general boundaries could be detected. Instead, faunal similarity was often exceptionally high around MLTL, and also high around MHTL, in some cases (Figs 15, 16). Presumably, these high similarities are an artefact of sample design. Stations 1 and 10 are both close to MLTL, and stations 90 and 99 close to MHTL. The horizontal distance between these sites was shorter than the distance to the respective other neighbouring sites. Similarly, the vertical distances of stations 90 and 99 (about $40 \mathrm{~cm}$ ) and stations 1 and 10 (about $40 \mathrm{~cm}$ ) are shorter than between 90-50, and 50-10 (about $65 \mathrm{~cm}$ ). Provided the faunal composition really changes gradually along the tidal gradient, a higher similarity of sites that are close together is not astonishing but to be expected. Accordingly, the higher similarity of Plathelminthes between mud 0 and 1 , and muddy sand 0 and 1 compared to the respective stations of sheltered and exposed sand may be an effect of varying distance between the sites. Mud 0 and muddy sand 0 samples were collected 2 to $3 \mathrm{~m}$ below MLTL, whereas the sublittoral sand was derived from $>15 \mathrm{~m}$ depth. Possibly the faunal gradient of Plathelminthes stretches further downward to increasing depths of sublittoral sediments.

Polychaeta and Oligochaeta were divided into a meiofaunal and a macrofaunal size class. The patterns of faunal similarity are very similar in some cases (see Oligochaeta Sørensen similarity in mud and muddy sand, Fig. 15), while they are the reverse in other cases (Renkonen similarity of Oligochaeta in muddy sand sites 1-50 and 10-50, Fig. 16). In the case of Oligochaeta, it seems a division into size classes is not helpful. Furthermore, it seems Oligochaeta do not fit into the benthic size distributions observed by Schwinghamer (1981) and Warwick (1984). In the taxon Polychaeta the situation is similar but less pronounced. Presumably because there are more species that can be exlusively attached to macro- or meiofauna, respectively.

In many cases, the faunal composition of Oligochaeta is quite similar over a large area (Fig. 15). In Polychaeta the number of 'dark spots' indicating high faunal similarity is smaller, and it is smallest in Plathelminthes. The situation is similar when comparing the 4 sediment types (Fig. 17). Thus, Oligochaeta seem to tolerate wide ranges of factors, and Plathelminthes relatively small ones. This is in good correlation with the number of species found: Plathelminthes are richest in species, and Oligochaeta poorest.

\section{The relation of macro- and meiofauna}

A correlation of macro- and meiofaunal per surface area abundances could not be found. Instead, when related to the occupied sediment volume, both macro- and meiofauna attain highest densities in mud and muddy sand. Macro- and meiofaunal 
densities are positively rather than negatively correlated. Epibenthic as well as endobenthic macrofauna may feed on meiofauna (Reise, 1985). Since most of the meiofauna is concentrated in the thin oxic layer of mud and muddy sand, these sediments should be most attractive to predators on meiofauna, compared to sheltered or exposed sand. On the other hand, macrofauna may promote meiofauna (Reise, 1985), and this should cause a positive correlation of macro- and meiofaunal abundance. Finally, macro- and meiofaunal species may compete for food (Schwinghamer, 1983).

The effect of macrofauna on meiofauna will depend on the relative influence of predators, promotors, and competitors. Because of varying environmental conditions and macrofauna-macrofauna species interactions, macrofaunal predators or competitors may have a stronger influence in one year, and promotors in another (see Warwick, 1982). It is therefore suggested that meiofaunal abundance will be most unstable in the sites of high macrofaunal activity (i.e. mud and muddy sand). Exposed beaches, on the other hand, are nearly devoid of macrofauna, so its effect on meiofauna is negligible. These sites are only characterized by meiofauna-meiofauna interactions and abiotic environmental factors (which, of course, also act on the meiofauna of mud and muddy sand). Therefore, exposed beaches are presumably most stable in meiofaunal abundance and faunal composition.

Acknowledgements. Karsten Reise is thanked for improving this manuscript by critical comments. P. Elvert and N. Kruse of R.V. 'Mya' provided technical assistance in sublittoral sampling. This study was supported by a grant of the Biologische Anstalt Helgoland.

\section{LITERATURE CITED}

Armonies, W., 1986. Free-living Plathelminthes in sheep-grazed and ungrazed supralittoral salt marshes of the North Sea: abundance, biomass, and their significance in food chains. - Neth. J. Sea Res. 20, 385-395.

Armonies, W., 1987. Freilebende Plathelminthen in supralitoralen Salzwiesen der Nordsee: Okologie einer borealen Brackwasser-Lebensgemeinschaft. - Microfauna mar. 3, 81-156.

Armonies, W. \& Hellwig, M., 1986. Quantitative extraction of living meiofauna from marine and brackish muddy sediments. - Mar. Ecol. Prog. Ser. 29, 37-43.

Cassie, R. M., 1972. Fauna and sediments of an intertidal mud-flat: an alternative multivariate analysis. - J. exp. mar. Biol. Ecol. 9, 55-64.

Gage, J. \& Geekie, A. D., 1973. Community structure of the benthos in Scottish sea-lochs. II. Spatial pattern. - Mar. Biol. 19, 41-53.

Hellwig, M., 1987. Okologie freilebender Plathelminthen im Grenzraum Watt-Salzwiese lenitischer Gezeitenküsten. - Microfauna mar. 3, 157-248.

Lindroth, A., 1971. On biocoenoses; coenotypes and coenoclines. - Thalassia jugosl. 7, 185-194.

Martens, P. M., 1984. Comparison of three different extraction methods for Turbellaria. - Mar. Ecol. Prog. Ser. 14, 229-234.

McLachlan, A., Winter, P. E. D. \& Botha, L., 1977. Vertical and horizontal distribution of sub-littoral meiofauna in Algoa Bay, South Africa. - Mar. Biol. 40, 355-364.

Mills, E. L., 1969. The community concept in marine zoology, with comments on continua and instability in some marine communities: a review. - J. Fish. Res. Bd Can. 26, 1415-1428.

Noldt, U. \& Wehrenberg, C., 1984. Quantitative extraction of living Plathelminthes from marine sands. - Mar. Ecol. Prog. Ser. 20, 193-201.

Reise, K., 1985. Tidal flat ecology. Springer, Berlin, $191 \mathrm{pp}$.

Sachs, L., 1984. Angewandte Statistik. Springer, Berlin, 552 pp.

Schmidt, P., 1968. Die quantitative Verteilung und Populationsdynamik des Mesopsammons am 
Gezeiten-Sandstrand der Nordseeinsel Sylt. I. Faktorengefüge und biologische Gliederung des Lebensraumes. - Int. Revue ges. Hydrobiol. 53, 723-779.

Schmidt, P., 1969. Die quantitative Verteilung und Populationsdynamik des Mesopsammons am Gezeiten-Sandstrand der Nordseeinsel Sylt. II. Quantitative Verteilung und Populationsdynamik einzelner Arten. - Int. Revue ges. Hydrobiol. 54, 95-174.

Schwinghamer, P., 1981. Characteristic size distributions of integral benthic communites. - Can. J. Fish. aquat. Sci. 38, 1255-1263.

Schwinghamer, P., 1983. Generating ecological hypotheses from biomass spectra using causal analysis: a benthic example. - Mar. Ecol. Prog. Ser. 13, 151-166.

Thorson. G., 1957. Bottom communities (sublittoral or shallow shelf). In: Treatise on marine ecology and paleoecology. Ed. by J. W. Hedgpeth. Geol. Soc. Am., New York, 1, 461-534. (Mem. geol. Soc. Am. 67.)

Uhlig, G., Thiel, H. \& Gray, J. S., 1973. The quantitative separation of meiofauna. A comparison of methods. - Helgoländer wiss. Meeresunters. 25, 173-195.

Warwick, R. M., 1982. The partitioning of secondary production among species in benthic communites. - Neth. J. Sea Res. 16, 1-16.

Warwick, R. M., 1984. Species size distribution in marine benthic communities. - Oecologia 61 , $32-41$.

Wehrenberg, C. \& Reise, K., 1985. Artenspektrum und Abundanz freilebender Plathelminthes in sublitoralen Sänden der Nordsee bei Sylt. - Microfauna mar. 2, 163-180. 